Biogeosciences Discuss., https://doi.org/10.5194/bg-2017-317

Manuscript under review for journal Biogeosciences

Discussion started: 25 August 2017

(c) Author(s) 2017. CC BY 4.0 License.

\title{
The Ballast Effect in the Indian Ocean
}

Tim Rixen ${ }^{1,2}$, Birgit Gaye ${ }^{2}$, Kay-Christian Emeis ${ }^{2,3}$, Venkitasubramani Ramaswamy ${ }^{4}$

${ }^{1}$ Leibniz Center for Tropical Marine Research, Bremen, 28359, Germany

$5 \quad 2$ Institute of Geology, University of Hamburg, Hamburg, 20146, Germany

${ }^{3}$ Helmholtz-Zentrum Geesthacht, Institute of Coastal Research, Geesthacht, 21502, Germany

${ }^{4}$ National Institute of Oceanography, Dona Paula, Goa, 403004, India

Correspondence to: Tim Rixen (Tim.Rixen@1eibniz-zmt.de)

Abstract. In this study, data obtained from a sediment trap experiments off South Java are analyzed and compared to

10 satellite-derived information on primary production and data collected by deep-moored sediment traps in the Arabian Sea and the Bay of Bengal. The aim was to study the relative importance of primary production and the ballast effect on the organic carbon export and the $\mathrm{CO}_{2}$ uptake of the biological carbon pumps. Therefore, data obtained from sediment trap experiments carried out in other ocean basins were also integrated into the data analysis and a four-box model was developed. Our data showed that the organic carbon flux in the highly-productive upwelling system in the Arabian Sea was

15 similar to those in the low productive system off South Java. Off South Java as in other river-influenced regions, lithogenic matter supplied from land mainly controls the organic carbon flux via its ballast effect in sinking particles, whereas carbonate produced by marine organisms appears to be the main ballast material in the high productive regions. Since the carbonate flux tends to increase with an increasing export production, it is difficult to quantify the relative importance of productivity and the ballast effect on the organic carbon flux into the deep sea. However, the export of organic matter into the deep sea represents a loss of nutrients for the pelagic ecosystems, which needs to be balanced by mode water nutrient supply into the seasonal thermocline to sustain the productivity of the pelagic system. The amount of preformed nutrients utilized during the formation of the exported organic matter strongly influences the impact of the ballast effect on the $\mathrm{CO}_{2}$ uptake of the organic carbon pump. Accordingly, this is stronger at higher latitudes where preformed nutrients are formed than at lower latitudes where the euphotic zone is nutrient depleted. Nevertheless, the ballast effect enhances the export of

25 organic matter into the deep sea and favors the sedimentation of organic matter in river-influenced regions. Since globally $>$ $80 \%$ of organic carbon burial occurs in river-dominated systems, the lithogenic ballast is assumed to play an important role in the Earth's climate system on geological time scales.

\section{Introduction}

Photosynthesis and precipitation of carbonate converts dissolved inorganic carbon into particulate organic and inorganic carbon. Their export from the sunlit surface ocean into the deep sea is an integral part of the organic carbon and the carbonate counter pump and strongly influences the Earth's climate (Volk and Hoffert, 1985). Due to opposing effects on the 
Biogeosciences Discuss., https://doi.org/10.5194/bg-2017-317

Manuscript under review for journal Biogeosciences

Discussion started: 25 August 2017

(c) Author(s) 2017. CC BY 4.0 License.

total alkalinity and resulting shifts of the carbonate system photosynthesis reduces the $\mathrm{CO}_{2}$ concentration in surface waters whereas the precipitation of carbonate increases the $\mathrm{CO}_{2}$ concentration (e.g. Zeebe and Wolf-Gladrow, 2001). Photosynthesis is, however, the ultimate driver of both pumps because it forms organic matter and transfers the sun's energy into chemical fuel required by marine organisms to precipitate carbonate. It is called primary production and it depends on

5 the availability of nutrients in the sunlit surface ocean (euphotic zone). Inputs from land via rivers and the atmosphere as e.g. aeolian dust are main sources of marine nutrients and once nutrients enter the ocean the ocean's circulation controls their availability for phytoplankton. It returns nutrients, which are released during the respiration of exported organic matter in the deep ocean into euphotic zone but it also withdraws nutrients from the surface layer by introducing them into the deep ocean by physical processes (Kwon et al., 2009; Sarmiento and Toggweiler, 1984; Siegenthaler and Wenk, 1984). Key sites at 10 which this occurs are regions of deep and mode water formation in the North Atlantic Ocean and the Southern Ocean. Here first of all upwelling and deep mixing entrains nutrients from the deep ocean into the surface mixed layer but the lack of light (e.g. in winter) and micronutrients such as iron (Falkowski et al., 1998) prevent the utilization of macronutrients (nitrate and phosphate). Subsequently, the mode- and deep-water formation returns these biologically unused nutrients into the interior of the ocean. These unused nutrients are termed preformed nutrients in contrast to regenerated nutrients, which are used to fix

$15 \mathrm{CO}_{2}$ during the photosynthesis and liberated during the respiration of exported organic matter in the deep sea. In addition to the availability of nutrients the depth at which the exported organic matter is respired influences the $\mathrm{CO}_{2}$ uptake of the organic carbon pump because the residence time of $\mathrm{CO}_{2}$ charged water in the deep ocean increases in general with increasing water depth (Ittekkot, 1993; Kwon et al., 2009).

Primary production rates are derived from satellite data (Antoine et al., 1996; Behrenfeld and Falkowski, 1997b) and avariety of equations have been developed to describe the carbon export into the deep sea as function of primary production and water-depth (Fig. 1, e.g, Berger et al., 1988; Bishop, 1989; Rixen et al., 2002; Suess, 1980). Other approaches focus on the link between primary production and the carbon export out of the euphotic zone referred to as export production (Eppley and Peterson, 1979; Laws et al., 2000) and independently from primary production on those between export production and organic carbon fluxes into the deep ocean (Armstrong et al., 2002; Martin et al., 1987). Contrary to primary production, which can be measured by the uptake of ${ }^{14} \mathrm{C}$ labelled $\mathrm{CO}_{2}$ (Nielsen, 1951) there are no reliable methods to measure export

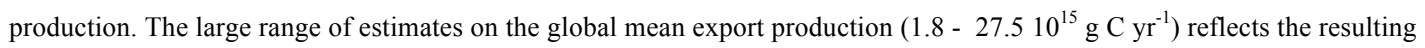
uncertainties (del Giorgio and Duarte, 2002; Honjo et al., 2008; Lutz et al., 2007). Based on numerical model results and ocean color data global mean export production rates ranging between 5 to $10 \mathrm{Pg} \mathrm{C} \mathrm{yr}^{-1}$ appear currently to be well accepted (Bopp et al., 2013; Westberry et al., 2012).

Phytoplankton can release up to $50 \%$ of the photosynthesized organic matter as dissolved organic carbon (DOC) into the water (Fogg, 1952; Fogg et al., 1965; Glibert and Bronk, 1994; Haas and Wild, 2010). The global mean DOC export of 1.8

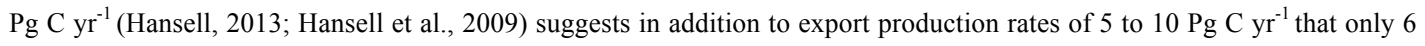
to $11 \%$ of the organic matter is exported as DOC. This implies that DOC is preferentially decomposed in surface waters and that the vast majority of the photosynthesized organic matter is exported as particulate organic carbon (POC). Compared to 
Biogeosciences Discuss., https://doi.org/10.5194/bg-2017-317

Manuscript under review for journal Biogeosciences

Discussion started: 25 August 2017

(c) Author(s) 2017. CC BY 4.0 License.

DOC, lower respiration of POC in the surface waters reflects fundamentally different export mechanism. As a dissolved component DOC stays in surface water and feeds the microbial food web until a strengthening of vertical mixing and a subsequent re-stratification exports it into subsurface waters. Since in the open ocean mixed layer depths hardly exceed 300 m DOC reaches the deep sea only at sites of deep water formation in the North Atlantic and Southern Ocean (de Boyer

5 Montégut et al., 2004). Contrary to this passive transport POC forms large particles sinking out of the mixed layer as soon as their density exceeds that of the ambient seawater (Smayda, 1971).

Sinking particles are separated into the three main groups: The first group contains larger organisms and their residuals (phytoplankton, zooplankton, fishes, and marine mammals) loosing the buoyancy after death of the respective organisms. The second group are fecal pellets produced by zooplankton and other higher organisms (Osterberg et al., 1963), and the third group are large amorphous aggregates referred to as marine snow (Suzuki and Kato, 1953). Marine snow reache sinking speeds of 16 to $368 \mathrm{~m} \mathrm{day}^{-1}$ and certain zooplankton species produce fecal pellets sinking with velocities of 862 to $2700 \mathrm{~m} \mathrm{day}^{-1}$ (Turner, 2002, and references therein).

Respiration is another factor determining if at all a particle reaches the deep sea. If respiration is too fast particles disappear before to they can reach the deep sea. Incubation experiments of individual particles indicate an exponential decay of organic matter in the water column (Ploug and Grossart, 2000).

$$
\operatorname{POC}(t)=\operatorname{POCo} * \mathrm{e}^{\left(-\lambda^{*} \mathrm{t}\right)}
$$

The velocity-determining factors are the initial amount of organic matter (POCo) and the decay constant $(\lambda)$. (t) represents the time during which the organic matter is exposed to bacterial and enzymatic attacks. $(\lambda)$ refers to the POC specific respiration rate, which is assumed to vary in a relative narrow range $\left(0.106 \pm 0.028\right.$ day $^{-1}$ (Iversen and Ploug, 2010; Ploug and Grossart, 2000). More recent studies based on in situ incubation experiments carried at water-depth $<500 \mathrm{~m}$ indicate respiration rates of $0.4 \pm 0.1$ and $0.01 \pm 0.02$ day $^{-1}$ in the subtropical North Atlantic Ocean and the Southern Ocean, respectively (McDonnell et al., 2015). This supports results obtained from laboratory and sediment trap studies suggesting that respiration rates are temperature dependent and decrease with decreasing temperatures (Iversen and Ploug, 2013; Marsay et al., 2015).

Applying equation 1 to calculate carbon fluxes in the water column (Banse, 1990) POCo represents the POC export from the euphotic zone (export production $=\mathrm{POC}_{\text {euphotic }}$ ) and the time $(\mathrm{t})$ results from water-depth and sinking speed of the particle ( $\mathrm{t}$ $=($ water-depth $(\mathrm{z})-$ depth of the euphotic zone $) /$ sinking speed $)$ :

30

$$
\operatorname{POC}(z)=\text { POC }_{\text {euphotic }} * \mathrm{e}^{(-\lambda *(z \text {-depth of the euphotic zone)/sinking speed })}
$$

Equation 2 indicate that an increasing sinking speed reduces the respiration and increase the organic carbon flux by lowering the time a particle is exposed to respiration in the water column. Tiny little products of rock weathering referred to as 
Biogeosciences Discuss., https://doi.org/10.5194/bg-2017-317

Manuscript under review for journal Biogeosciences

Discussion started: 25 August 2017

(c) Author(s) 2017. CC BY 4.0 License.

lithogenic matter supplied from land as dust and as suspended matter by rivers was assumed to increase the organic carbon fluxes if they are incorporated into particles and accelerate their sinking (Haake and Ittekkot, 1990; Ittekkot and Haake, 1990; Ittekkot et al., 1992).

This so-called "ballast effect" emerged as a sort of side effect by studying the sedimentation of clay minerals in the deep-sea.

5 According to Stoke's law such minerals are too small to sink and should stay as suspended solids in the water column (McCave, 1975) raising the question of how clay with grain sizes $<2 \mu \mathrm{m}$ reaches the deep sea and accumulate in sediments (Rex and Goldberg, 1958). Rex and Goldberg (1958) suggested that the incorporation of lithogenic matter into biologically produced aggregates enable the transfer of dust into sediments and studies in lakes and the coastal ocean demonstrated the relevance of the interaction between clay and sticky polysaccharides released by plankton for the flocculation of fast sinking aggregates (Avnimelech et al., 1982; Kranck, 1973). In the open ocean, fecal pellets were suggested to play a crucial role for the transport of dust from the ocean's surface into the deep sea (Honjo, 1976, 1982; McCave, 1984, 1975). The perspective changed as sediment trap results from the Arabian Sea in the northern Indian Ocean showed that wind speeds, organic carbon and lithogenic matter fluxes revealed the same seasonality (Haake and Ittekkot, 1990; Ittekkot, 1993; Ittekkot et al., 1992; Ramaswamy et al., 1991). Aeolian dust inputs were considered as an active driving force increasing organic carbon

15 fluxes by accelerating the sinking of particles into the deep sea.

First experiments on particle formation by using rolling tanks confirmed the ballast-effect in so far as they showed that sinking speed of marine snow produced by diatoms increased from $230 \mathrm{~m} \mathrm{day}^{-1}$ to $860 \mathrm{~m} \mathrm{day}^{-1}$ (Hamm, 2002). Lithogenic matter was not only trapped and passively integrated into aggregates it also interacted actively with the organic matter. This accelerated flocculation and reduced the aggregate size. Since larger particles sink faster than smaller ones the reduction of aggregate sizes decreases sinking speeds but the associated increase in density overcompensates this breaking effect. The increase of particle sinking speeds caused by the incorporation of minerals into particles defines the ballast effect whereas the type of minerals and the capability of organic matter to trap it strongly influence the strength of the ballast effect (Alldredge and McGillivary, 1991; Deng et al., 2015; Iversen and Robert, 2015).

The organic carbon content of particles formed in rolling tanks range between 2 and $5 \%$ (De La Rocha et al., 2008) and

25 resembles those of organic matter in particles collected by sediment traps in the deep sea all over the world (5 and 7 \%)(Armstrong et al., 2002; Francois et al., 2002; Klaas and Archer, 2002). These contents were accordingly assumed to reflect the organic carbon carrying capacity of minerals in sinking particles (Armstrong et al., 2002). Similar to concepts in sedimentology where the preservation of organic matter is considered as a function of its adsorption to mineral surfaces (Keil, 2011; Keil and Hedges, 1993) Armstrong et al., (2002) emphasized the protection of organic matter by the mineral ballast and distinguished two types of organic matter in sinking particles (Fig. 1). The one is free (POC $)$ and exposed to bacterial and enzymatic attacks and the other one is attached to minerals and thereby protected against respiration $\left(\mathrm{POC}_{\mathrm{P}}\right)$. The free organic matter was assumed to be exponentially decomposed:

$\operatorname{POC}_{\mathrm{F}}(\mathrm{z})=\mathrm{POC}_{\text {Feuphotic }} * \mathrm{e}^{\text {(z-euphotic zone/ })}$ 
Biogeosciences Discuss., https://doi.org/10.5194/bg-2017-317

Manuscript under review for journal Biogeosciences

Discussion started: 25 August 2017

(c) Author(s) 2017. CC BY 4.0 License. remineralization corresponds to the quotient of sinking speed and decay constant $(\delta=\operatorname{sinking}$ speed $/ \lambda)$. The dissolution and dissociation reduces the mineral ballast flux and enables also the decomposition of the protected organic carbon but to a 5 much lesser extend.

The correlation between organic carbon and calcium carbonate fluxes obtained from a global compilation of sediment trap data indicated however, that calcium carbonate instead of lithogenic matter is the most important ballast mineral (Armstrong et al., 2002; Francois et al., 2002; Klaas and Archer, 2002; Lutz et al., 2002). In this paper we compiled and analyzed sediment trap data collected by deep moored sediment traps at fifteen sites with the aim to study the influence of the ballast 10 effect and on the organic carbon export in the Indian Ocean (Fig. 2, Tab. 1, 2). Haake et al. (1993) and Rixen et al (1996) described the methods. Furthermore a four-box model was developed to estimate the potential impact of the ballast effect on the $\mathrm{CO}_{2}$ uptake of the ocean.

\section{Study Area}

\subsection{Monsoon and Surface Ocean Circulation}

15 The monsoon strongly influences the surface ocean circulation in the Indian Ocean (e.g., Ramage, 1971) and can be considered as a giant land-sea breeze (Gadgil et al., 2007; Wang, 2009). It develops between the Asian land mass and the Indian Ocean and owes its existence to the meridional migration of the sun and the differential heating of land and water. This fortifies the cooling in winter and the heating of the atmosphere over the Asian landmass in summer. The summer heating enforces the southern hemispheric SE trade winds to cross the equator forming the low-level-cross equatorial Findlater Jet Stream (Findlater, 1977). The Findlater Jet interrupts the world's encompassing tropical high-precipitation and low-pressure belt referred to as the Inter Tropical Convergence Zone (ITCZ) in the western Indian Ocean and the summer heating shifts the ITCZ northwards towards the southern flanks of the Himalayan mountain range (Fig. 3). The monsoon influences also neighbouring land masses due to which the Asian monsoon is separated into four subsystems: the north African, the Indian, the East Asian, and the Indonesian-Australian monsoon (e.g., Wang et al., 2005 and references therein).

25 NE trade winds blowing over the northern hemispheric part of Indonesian Archipelago turn into NW winds after crossing the equator due to the change of the Coriolis force characterize the Indonesian-Australian monsoon during the boreal winter. The associated southward displacement of the ITCZ introduces the rainy seasons (Fig. 3). At the beginning of the boreal summer the ITCZ moves northwards, the southern hemispheric SE trade wind replace the NW winds over the South Java Sea south of the equator and lower the precipitations rates over Indonesia.

30 The Indonesian Archipelago and the southern part of the Himalayan Mountain range are among the regions characterized by the highest precipitation rates worldwide. Unlike the Indian subcontinent, Indonesia has no major rivers but the numerous small Indonesian rivers contribute $\sim 11 \%\left(4.3 * 10^{12} \mathrm{~m}^{3} \mathrm{yr}^{-1}\right)$ to the global freshwater discharge into the ocean (Syvitski et al., 
Biogeosciences Discuss., https://doi.org/10.5194/bg-2017-317

Manuscript under review for journal Biogeosciences

Discussion started: 25 August 2017

(c) Author(s) 2017. CC BY 4.0 License.

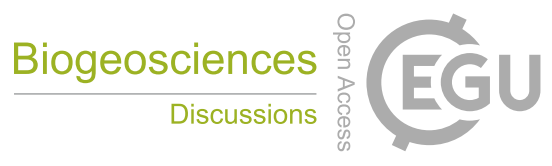

(c) (i)

2005). This even exceeds those of the Indus and the Ganges-Brahmaputra $\left(\begin{array}{lllll}0.1 & * & 10^{12} & \mathrm{~m}^{3} \mathrm{yr}^{-1}\end{array}\right.$ (http://www.sage.wisc.edu/riverdata/) draining the southern part of the Himalayan mountains, whereas it should be noted that today humans regulate the discharge of almost all these rivers. Nevertheless, due to the high freshwater fluxes the Indonesian Seas and the western Indian Ocean are characterised by low salinity surface waters whereas a freshwater inputs

5 falling below evaporation rates leads to the formation the high salinity Arabian Sea Water (ASW).

The monsoon winds reverse the surface ocean circulation in the Indian Ocean (Fig. 3-4, Schott and McCreary, 2001). In winter the NE trade winds establish a counter clockwise surface ocean circulation in the Arabian Sea and the Bay of Bengal. In the equatorial region the surface circulation resembles those in the Pacific and Atlantic Oceans with a well-established South Equatorial Current and a South Equatorial Counter Current (SECC, Schott and McCreary, 2001). During the summer the SECC disappears and an eastwards flow establishes north of the equator where all the major currents reverse. The now clockwise circulation supplies high salinity Arabian Sea Water into the eastward flowing Southwest Monsoon Current, which feeds into the clockwise circulation of the Bay of Bengal. Following the monsoon-driven seasonality the eastwards flowing South Java Current (SJC) also reverses if the SE trade winds move northward during the boreal the summer (Quadfasel and Cresswell, 1992). In summer the positive wind stress curl causes upwelling in the Arabian Sea, which is

15 strongest along the coast of the Arabian Peninsula (Fig. 3-4a, Bauer et al., 1991; Luther and O'Brien, 1990; Ryther and Menzel, 1965; Sastry and D'Souza, 1972). Contrary to the Atlantic and Pacific Oceans where major eastern boundary upwelling systems establish off California, NW Africa, Peru and Namibia/South Africa, the only upwelling system in the eastern Indian Ocean develops off South Java and Bali (Susanto et al., 2001).

\subsection{Organic Carbon Export}

20 Sediment trap experiments were carried during the Joint Global Ocean Flux Studies in the Arabian Sea (JGOFS Indik) between 1994 and 1995 (Honjo et al., 1999; Lee et al., 1998). These studies complemented the Indo/German sediment traps program, which started in 1986 and was expanded into in the Bay of Bengal in 1987 (Fig. 3-2, Haake et al., 1993; Ittekkot et al., 1991; Nair et al., 1989; Rixen et al., 2009). Between 2001 and 2004 additional sediment trap experiments were carried out in the upwelling system off South Java (Mohtadi et al., 2009; Rixen et al., 2005; Romero et al., 2009). The results obtained from the sediment trap programs in the Arabian Sea are accessible at https://doi.org/10.1594/PANGAEA.879702 and showed that the organic carbon fluxes in the deep sea follow the monsoon-driven surface ocean processes and reveal high fluxes during the summer and winter monsoon (Fig. 5). Upwelling induced by the monsoon winds in summer and vertical mixing favoured by winter cooling were the respective processes through which the monsoon increased the nutrient supply into the euphotic zone and organic matter export into the deep sea. In the Bay of Bengal the heavy monsoon rain and the resulting river discharges are additional nutrient sources to the euphotic zone. The riverine nutrient discharges increase the organic carbon fluxes near the coast but the freshwater-induced enhanced stratification reduced vertical mixing and nutrient inputs from below the mixed layer into the euphotic zone furtherer offshore. The resulting monsoon-driven seasonality of the organic carbon fluxes are much lower in the Bay of Bengal as in the Arabian Sea except in the southern 
Biogeosciences Discuss., https://doi.org/10.5194/bg-2017-317

Manuscript under review for journal Biogeosciences

Discussion started: 25 August 2017

(c) Author(s) 2017. CC BY 4.0 License.

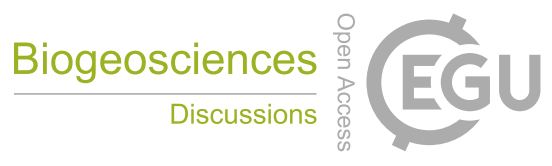

(c) (i)

Bay of Bengal at the station SBBT. Upwelling occurring off southwest India and the Sri Lanka Dome influenced the sediment trap site SBBT (Unger et al., 2003), due to which the organic carbon fluxes revel a seasonality similar to those recorded by the sediment traps in the Arabia Sea.

Organic carbon fluxes were measured over a period of seven and more years at two sites in the Arabian Sea (WAST and

5 EAST) and two locations in the Bay of Bengal (NBBT-N and SBBT). At these sites the interannual variability of the annual mean organic carbon fluxes were $< \pm 15 \%$. In the Arabian Sea opposing effects of the monsoon-driven lateral (water mass exchange) and vertical water mass transport (upwelling and vertical mixing) on the nutrient supply into the euphotic zone, were assumed to reduce the internannual variability in addition to the intensities of the summer and winter monsoons which are inversely related to each other (Rixen et al., 2014).

10 In the South Java Sea at our trap site JAM the organic carbon flux reflects the monsoon-caused seasonality with enhanced fluxes at the end of the rainy season in March and during the boreal summer in August/September whereas these two seasons correspond to the winter and summer monsoon in the northern Indian Ocean (Fig. 6). The enhanced summer fluxes were assumed to be caused by upwelling whereas phytoplankton blooms triggered by increased riverine nutrient inputs was suggested to explain the enhanced fluxes at the end of the rainy season (Mohtadi et al., 2009; Rixen et al., 2006; Romero et

15 al., 2009).

Contrary to sediment trap experiments in the Arabian Sea and the Bay of Bengal, which were conducted mainly prior to 1998 the sediment trap experiment off South Java overlaps with the "Sea-viewing Wide Field-of-view Sensor" Mission (SeaWiFS) which was launched in 1997 (McClain et al., 2004). Satellite derived primary production rates derived from the 'Vertically Generalized Production Model, VGPM)' (Behrenfeld and Falkowski, 1997a, b) were downloaded from the web

20 site 'ocean productivity' (O'Malley, 2015). This data covering the period between years 2002 to 2015 were selected for an area of $\pm 1^{\circ}$ around the trap sites and converted into monthly means to be compared with the sediment trap data from the northern Indian Ocean (Fig. 7). Off South Java satellite and sediment trap data could also be directly linked to each other (Fug. 8).

\section{Results and Discussion}

\section{3.1 Primary Production and Organic Carbon Fluxes}

In the South Java Sea satellite-derived enhanced primary productions rates correspond to high organic carbon fluxes during the upwelling season but enhanced fluxes are not reflected in higher primary production rates during the rainy season (Fig. 8 , 9). A dense cloud cover shading the surface ocean from space observations could have caused this decoupling during the rainy season (Hendiarti et al., 2004). Although the same problem occurs in summer during the upwelling season in the Arabian Sea (Banse and English, 2000, 1994) the long-term mean organic carbon flux and primary production rates reveal the same seasonality (Fig. 8). However, in summer primary production rates in the Arabian Sea are higher as off South Java whereas the organic carbon flux off South Java exceeds those in the western Arabian Sea. The enhanced export of organic 
Biogeosciences Discuss., https://doi.org/10.5194/bg-2017-317

Manuscript under review for journal Biogeosciences

Discussion started: 25 August 2017

(c) Author(s) 2017. CC BY 4.0 License.

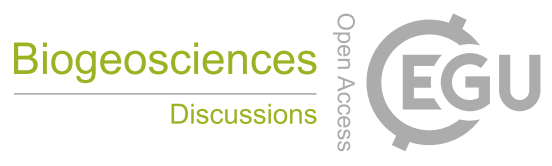

(c) (i)

matter in a relatively low productive and weaker upwelling system suggests that a less efficient respiration of organic matter increases the organic carbon flux off South Java.

In order to test this hypothesis and to identify the responsible processes the monthly mean primary production rates obtained from our trap sites (Fig. 3.7) were converted into export production based on the equation provided by Eppley and Peterson

5 (1979). The resulting monthly mean export production rates and the mean organic carbon fluxes shown in figure 5 were averaged for the summer (June - September), winter (January - April) and intermonsoon periods (May and October to December). The difference between the seasonally averaged export production rates and seasonal averaged organic fluxes represent seasonal mean respiration rates. The share of the exported organic matter, which reached the sediment traps and which was respired in the water column was plotted against the calculated export production rates (Fig. 10 a). The resulting

10 trend follows Michaelis-Menten kinetics and implies that the share of the exported organic matter, which is respired increase with an increasing export production rates. Such a rising respiration efficiency with an increasing productivity agrees also to results obtained from a global compilation of sediment trap data (Francois et al., 2002).

The data obtained from the Bay of Bengal and the South Java Sea deviate from this trend and scatter around the trend line. These deviations were quantified by calculating organic carbon fluxes based on the primary production rates, the Eppley and

15 Peterson equation, and the Michaelis-Menten kinetics presented in the figure 10a. The difference between measured fluxes and those derived from primary production was considered as excess organic carbon flux $\left(\mathrm{POC}_{\mathrm{Excess}}\right)$ indicating how much higher the organic carbon was as expected from the primary production. The excess organic carbon flux correlates best with the lithogenic matter content suggesting that increasing contribution of lithogenic matter and thus its ballast effect increased the excess organic carbon flux (Fig. 10b).

20 We repeated the analysis and used a global compilation of sediment trap data presented by Wilson et al. (2012). Since this data were annual means we converted our data also into annual means, added it to the global data set, and selected annual mean primary production rates for all trap locations. The results imply that the recycling efficiency decreases with an increasing productivity in the Indian Ocean, but there are many exception indicating that also in low productive regions the recycling efficiency is with $>99 \%$ as high as in high productive regions (Fig. 11a). This points to spatial and temporal

25 variability of the ballast effect, which was studied in further detail by analyzing factors controlling the sinking speed of particles in the ocean.

\subsection{Ballast Effect}

\subsubsection{Sinking Speeds}

Stoke's law derived from the Navier-Stoke equation is an often used parameterization for calculation sinking velocity (U) of 30 particles (e.g., Lal and Lerman, 1975; McCave, 1975; Miklasz and Denny, 2010):

$\mathrm{U}=\left(\left(2 * \mathrm{~g} * \Delta \rho *\right.\right.$ radius $\left.^{2}\right) /(9 \eta)$ 
Biogeosciences Discuss., https://doi.org/10.5194/bg-2017-317

Manuscript under review for journal Biogeosciences

Discussion started: 25 August 2017

(c) Author(s) 2017. CC BY 4.0 License.

where $(\mathrm{g})$ is the gravitational acceleration, $(\Delta \rho)$ represents the excess density of particles over water, (radius) defines the radius sinking particle, whereas particles are considered to be spheres. $(\eta)$ is the viscosity of the fluid. The excess density is the density difference between the density of the particle $\left(\rho_{\text {particle }}\right)$ and the sea water $\left(\rho_{\text {seawater }}\right)$.

5

$\Delta \rho=\rho_{\text {particle }}-\rho_{\text {seawater }}$

If the particles are larger and the Reynolds number exceeds one the Navier-Stoke drag equation should be used to calculate sinking velocities (e.g., Alldredge and Gotschalk, 1988; Engel et al., 2009; Iversen and Ploug, 2010). The Reynolds number

$$
\begin{aligned}
& \mathrm{Re}=\mathrm{U} * \text { radius } * \rho_{\text {seawater }} / \eta \\
& \mathrm{U}=\left((2 * \mathrm{~g} * \Delta \rho) /\left(\rho_{\text {seawater }} * \mathrm{C}_{\mathrm{D}}\right) *(\text { area } / \text { volume })\right)^{0.5}
\end{aligned}
$$

$$
\mathrm{C}_{\mathrm{D}}=(24 / \mathrm{Re})+\left(6 /\left(1+\mathrm{Re}^{0.5}\right)\right)+0.4
$$

In the ocean sinking particles cover a size spectrum with an equivalent spherical diameter (ESD) ranging mostly between 0.01 and $<5 \mathrm{~mm}$ (Guidi et al., 2009; Iversen et al., 2010) whereas an ESD of $0.1 \mathrm{~mm}$ is often considered as thresholds dividing small and large particles (Durkin et al., 2015; Guidi et al., 2009). Particles formed in the rolling tanks often exceed $1 \mathrm{~mm}$, reached ESDs of $>1 \mathrm{~cm}$, and resemble in size marine snow collected by scuba divers in the surface water of the ocean revealing ESDs of up to $7.5 \mathrm{~cm}$ (Alldredge and Gotschalk, 1988; Engel et al., 2009). Due this wide range of ESDs and Reynolds numbers, which increase with increasing sinking speeds Stokes law and the Navier-Stokes drag equation are both used to calculate sinking velocities of marine particles. Their results are incongruent at a Reynolds number of 1 but, however, both equations show that particle density $\left(\rho_{\text {particle }}\right)$ and size influence the sinking velocities. The larger and denser the particle is the faster it sinks. This lead to the general assumption that larger plankton forms larger and thus faster sinking particles (e.g., Michaels and Silver, 1988; Smayda, 1970). In situ observations, however, show that large particles arriving at a water-depth of $380 \mathrm{~m}$ sank much slower than smaller particles (Asper, 1987) whereas other studies revels no regular link between particle size and sinking velocity (McDonnell and Buesseler, 2012). The deviation of the particle shape from a sphere as well as the varying particle densities could explain such irregular pattern.

The density of particle results from their pore water and the density of solid material:

$$
\rho_{\text {particle }}=\left(\text { porosity } * \rho_{\text {water }}\right)+(1 \text {-porosity }) * \rho_{\text {solids }}
$$


Biogeosciences Discuss., https://doi.org/10.5194/bg-2017-317

Manuscript under review for journal Biogeosciences

Discussion started: 25 August 2017

(c) Author(s) 2017. CC BY 4.0 License.

The composition of the particles collected in the sediment traps and the density of bulk components (D) can be used to estimate the density of the solids:

$5 \quad \rho_{\text {solids }}=\left(\left(\mathrm{Lith} \% * \mathrm{D}_{\text {lith }}\right)+\left(\mathrm{OM} \% * \mathrm{D}_{\text {om }}\right)+\left(\mathrm{Opal} \% * \mathrm{D}_{\text {opal }}\right)+\left(\mathrm{Carb} \% * \mathrm{D}_{\text {carb }}\right)\right) / 100$

In combination with equation 2,4 , and 9 the equation 10 can be used to estimate the impact of a changing lithogenic matter content on the sinking speed and the export of organic matter into the deep sea. However, prior to use these equations, the density of the bulk components needs to be estimated.

10 3.2.2 Density of the Bulk Components

Except lithogenic matter the bulk components of the material collected by sediment traps were produced by marine organisms and reveal a density falling below the density of their crystalline analogs (Fig. 12). For example, the density of proteins varies between 1.22 to $1.47 \mathrm{~g} \mathrm{~cm}^{-3}$ whereas the density of organic matter in phytoplankton consisting to $>80 \%$ of amino acids varies between 1.03 and $1.1 \mathrm{~g} \mathrm{~cm}^{-3}$ (Lee et al., 2004; Logan and Hunt, 1987; Miklasz and Denny, 2010; Quillin

15 and Matthews, 2000). Similar to amino acids carbohydrates can reach a density of up to $1.8 \mathrm{~g} \mathrm{~cm}^{-3}$ but the density of transparent exopolymers (TEP) excreted by plankton and consisting of mucopolysaccharids varies between $0.7-0.84 \mathrm{~g} \mathrm{~cm}^{-3}$ (Azetsu-Scott et al., 2004).

The density of calcite, the most common calcium carbonate mineral in the pelagic ocean, is $2.71 \mathrm{~g} \mathrm{~cm}^{-3}$ (Mottana et al., 1978 ) and those of opal a hydrous silicon oxide ranges between 1.9 to $2.5 \mathrm{~g} \mathrm{~cm}^{-3}$. The density of diatom frustules (biogenic

20 opal) varies between 1.46 and $2.0 \mathrm{~g} \mathrm{~cm}^{-3}$ (Csögör et al., 1999; DeMaster, 2003) and coccolithophores reveal a density of only $1.55 \mathrm{~g} \mathrm{~cm}^{-3}$ (page 71, Winter and Siesser, 1994). The densities derived from sinking speed of foraminifera shells (Schiebel et al., 2007; Schiebel and Hemleben, 2000) reach values of up to $1.7 \mathrm{~g} \mathrm{~cm}^{-3}$. The variability of the density of biogenic bulk components implies that marine plankton influences it and that the bulk composition of sediment trap samples collected in various regions of the ocean is a poor indicator of the ballast effect. Lithogenic matter hardly improves this situation because

25 it is a diverse assemblage of tiny minerals, which also differ with respect to their densities.

At our trap sites quarz and the clay mineral illite mostly compose lithogenic matter (Ramaswamy et al., 1991; Ramaswamy et al., 1997) and the density of these two minerals is $2.72 \mathrm{~g} \mathrm{~cm}^{-3}$. Clay is a grain size (radius $<0.02 \mathrm{~mm}$ ) and a mineral group, which partly change their density by adsorbing water. This is most pronounced within the group of smectite which density decreases from 2.72 to $1.4 \mathrm{~g} \mathrm{~cm}^{-3}$ during its hydration (Osipov, 2012). However, a density $2.72 \mathrm{~g} \mathrm{~cm}^{-3}$ might be a realistic estimate for the density of lithogenic matter at our tarps site since quarz and illite dominate its composition. Ignoring the variability of density of the other bulk components and just consider their means the density of solids can be calculated as follows (Tab. 2):

$\rho_{\text {solids }}=((\operatorname{Lith} \% * 2.72)+(\operatorname{Corg} \% * 1.065)+(\mathrm{Opal} \% * 1.73)+(\operatorname{Carb} \% * 1.625)) / 100$ 
Biogeosciences Discuss., https://doi.org/10.5194/bg-2017-317

Manuscript under review for journal Biogeosciences

Discussion started: 25 August 2017

(c) Author(s) 2017. CC BY 4.0 License.

The mean composition of particles collected at our trap sites is given in the tables 2 and implies that the density of the solids varied between 1.7 and $2.4 \mathrm{~g} \mathrm{~cm}^{-3}$. On average carbonate and lithogenic matter contribute approximately $30 \%$ to the total density of the solid. The correlation between lithogenic matter content and density of the solid indicate furthermore that

5 lithgogenic matter largely controls the variability of the density of the solids (Fig. 13 a).

Prior to estimate the influence of the density of the solids on the organic carbon flux a variety of other parameters have to be estimated, which in addition to the density of the solid control the organic carbon flux and the sinking speed of particles.

\subsubsection{Quantification of the Ballast Effect}

The impact of the density of the solids on the organic carbon flux defines the ballast effect and can be calculated by combining equations $2,4,5,9,10$ and 11 . In order to use these equations the export production and the organic carbon flux (Eq. 2) as well as the radius of the particle (Eq. 4), the viscosity and density of seawater (Eq. 4) and the porosity of particle (Eq. 9) have to be determined. To come up with reliable estimates of these data a first numerical experiment was carried out (see Tab. 3 - Experiment 1). In second experiment we fixed this parameters and changed the density of solids to recalculate the organic carbon fluxes, which were compared with the measured ones.

15 The first task in the first experiment was to determine the annual mean sinking speed of particles by solving equations 2 for sinking speed. The required annual mean primary production of the Arabian Sea of $205 \mathrm{~g} \mathrm{~m}^{-2} \mathrm{year}^{-1}$ was obtained from Rixen et al (2002) and the equation introduced by Eppley and Peterson (Eppley and Peterson, 1979) was used to convert the primary production into export production $\left(105 \mathrm{~g} \mathrm{~m}^{-2} \mathrm{year}^{-1}\right)$. Assuming a depth of the euphotic zone of $100 \mathrm{~m}$ and decay constant $(\lambda)$ of 0.106 day $^{-1}$ the export production and the mean organic carbon flux measured by our traps $\left(2.74 \mathrm{~g} \mathrm{~m}^{-2}\right.$ year $^{-1}$,

20 see Tab. 2) at water-depth of approximately $3000 \mathrm{~m}$ were used to calculate an annual mean sinking speed of particles. The resulting sinking speed of $84.5 \mathrm{~m} \mathrm{day}^{-1}$ was in the second step used to estimate the porosity of sinking particles by combining equations 4,5 and 9 . Therefore we choose a particle radius of $0.1 \mathrm{~cm}$ because particles with radius of 0.05 to $0.1 \mathrm{~cm}$ are mainly responsible for the transport of material into the deep sea in the upwelling system of NW Africa (Iversen et al., 2010). Furthermore, a temperature of $10^{\circ} \mathrm{C}$ and a salinity of 35 was selected to calculate the viscosity and density of seawater (Wagner and Pruß, 2002) and a mean density of the solid of $1.86 \mathrm{~g} \mathrm{~cm}^{-1}$ was considered as obtained from our data (Tab. 2) to calculate the porosity of sinking particles.

The second experiment aimed at quantifying the possible ballast effect. Therefore all data were kept constant except the organic carbon flux and the density of the solids (Tab. 3 - Experiment 2). The regression equation obtained from the correlation between lithogenic matter content and the density of the solid was used to translate changes in the lithogenic matter content into the density of the solid (Fig. 3.13a) and the equation 2 and 4 were combined to calculate the organic carbon fluxes at a water-depth of $3000 \mathrm{~m}$. The resulting organic carbon fluxes increased with an increasing lithogenic matter content and reveal a variability exceeding those measured by the traps (Fig. 13b). This implies that the ballast-effect could suffice to explain the variability of organic carbon fluxes measured by our sediment traps. 
Biogeosciences Discuss., https://doi.org/10.5194/bg-2017-317

Manuscript under review for journal Biogeosciences

Discussion started: 25 August 2017

(c) Author(s) 2017. CC BY 4.0 License.

A sinking speed of only $84.5 \mathrm{~m}$ day $^{-1}$ implies that particles require 35 days to reach the a water-depth of about $3000 \mathrm{~m}$. The correlation between surface ocean processes such as onset of upwelling and the resulting increase of organic fluxes measured at water-depth of about $3000 \mathrm{~m}$ indicate a mean delay of only 14 days (Rixen et al., 1996). This delay calls for a mean sinking speed of $>214 \mathrm{~m} \mathrm{day}^{-1}$, which agrees to results obtained form U.S. JGOFS sediment traps experiment in the Arabian 5 Sea $\left(230 \pm 72 \mathrm{~m} \mathrm{day}^{-1}\right)$ (Berelson, 2001).

In order to see whether sinking speeds of $<200 \mathrm{~m}^{-1} \mathrm{y}^{-1}$ are consistent with our calculations two more experiments were carried out. Within the first of these two experiments (experiment 3 ) all parameters were kept constant and the sinking speed of $214 \mathrm{~m} \mathrm{day}^{-1}$ was in addition to the mean organic carbon flux of $2.75 \mathrm{~g} \mathrm{~m}^{-2}$ year $^{-1}$ used to recalculate the export production (Tab. 3 - Experiment 3). Using equation 2 and a decay constant of 0.106 day $^{-1}$ this amounts to an export production of only $1011.75 \mathrm{~g} \mathrm{~m}^{-2}$ year $^{-1}$ representing only $11 \%$ of the satellite-derived export production rate of $105 \mathrm{~g} \mathrm{~m}^{-2}$ year $^{-1}$. This indicates that due to the reduced respiration in fast sinking particles an export production of $11.75 \mathrm{~g} \mathrm{~m}^{-2}$ year ${ }^{-1}$ suffice to explain the measured organic carbon flux. The remaining $89 \%$ of the exported organic carbon could be exported in slow sinking particles, which were respired at shallower water-depth. The notion of slow and fast sinking particle is not new and similar to the concepts of Armstrong et al. (2002) who divided the export production into large free and a comparable small ballast

15 protected fractions (Fig. 1).

The experiment 4 was carried out to test whether the lithogenic ballast effect could also explain the observed organic carbon fluxes if one assumes that only $11 \%$ of the export production is carried by fast sinking particle into the deep sea (Tab. 3 Experiment 4). Hence, instead of an export production of $105 \mathrm{~g} \mathrm{~m}^{-2}$ year ${ }^{-1}$ and a sinking speed of $84.5 \mathrm{~m} \mathrm{day}^{-1}$ we used an export production and a sinking speed of $11.75 \mathrm{~g} \mathrm{~m}^{-2}$ day $^{-1}$ and of $214 \mathrm{~m} \mathrm{day}^{-1}$, respectively. The calculated organic carbon fluxes agreed quite well the measured ones (Fig. 3-13b) suggesting that even if only fast sinking particles reach the deep sea the ballast effect could largely explain the observed organic carbon fluxes. Nevertheless, there some exceptions showing enhanced organic fluxes although the lithogenic matter content was relatively low.

The density of the solids and the annual mean organic carbon fluxes measured by our sediment traps and those deployed in 1994/95 during the U.S. JGOFS support the results obtained from our numerical experiments. The density of the solids correlates with the organic carbon export whereas exceptions occur, which are characterized by high organic carbon fluxes and low densities (Fig. 14a). The correlation is based on data measured in the river influenced regions whereas the data from the upwelling dominated areas in the Arabian Sea and the southern Bay of Bengal are the exceptions.

These exceptions correlate to the flux of carbonate carbon (Fig. 14b) suggesting that carbonate act as mineral ballast in marine dominated regions. This support results obtained from global compilations (Fig. 3-14b, Francois et al., 2002; Klaas and Archer, 2002). Accordingly, lithogenic matter seems to be the main ballast mineral in the river (land)-influenced regions where precipitation of carbonate controls the ballast effect in the open ocean areas including the upwelling-dominated regions in the northern Indian Ocean. Since enhanced and low fluxes of carbonate carbon are often associated with high and low export production rates (Fig. 11c) it is difficult to quantify the relative importance of productivity and the carbonate ballast on the carbon export into the deep sea in marine dominated systems. 
Biogeosciences Discuss., https://doi.org/10.5194/bg-2017-317

Manuscript under review for journal Biogeosciences

Discussion started: 25 August 2017

(c) Author(s) 2017. CC BY 4.0 License.

Contrary to the river-influenced regions in the northern Indian Ocean the global compilation of sediment trap data show no correlation between the organic carbon fluxes and lithogenic matter content (Fig. 13c). Even at sites at which the lithogenic matter content was high the organic carbon flux into the deep sea was low. This could mean that the production of organic matter was simply too low to sustain a high export production and/or varying densities of the supplied clay could have

5 caused it (Fig. 12). However, the resulting question is actually why at all pelagic ecosystems export organic matter?

\subsection{Ecosystem Function and Sensitivity to Climate Change}

The export and respiration of organic matter into and in the deep sea introduces nutrients into the long-term overturning circulation of the ocean, which withdraws nutrients from the pelagic ecosystem and lowers their productivity (Heinze et al., 1991). In contrast, the respiration of organic matter within the seasonal thermocline would prevent this nutrient loss and keep

10 it accessible to the pelagic ecosystems on a seasonal cycle. The seasonal thermocline defines the subsurface layer from which water is introduced into the euphotic on the seasonal times scale. In the Arabian Sea upwelled water originates approximately at a water-depth of down to approximately $350 \mathrm{~m}$ (Rixen et al., 2000a; Rixen et al., 2000b) which corresponds to the water-depth at which the majority of particles disappear in the upwelling systems off NW African (Guidi et al., 2009; Iversen et al., 2010). In the Arabian Sea it corresponds to the depth at which the secondary nitrite maximum 15 (SNM) is located which indicates the zone of active denitrification (Fig. 3-15, Naqvi, 1991; Rixen et al., 2014). Denitrification during which nitrate is reduced to $\mathrm{N}_{2}$ to decompose exported organic matter occurs due to the lack of dissolved oxygen. Since oxygen concentrations remain low $(>5 \mu \mathrm{M})$ and nitrate concentrations even increase below SNM one could assume that the decomposition of organic matter is extremely low and largely restricted to the upper part of the oxygen minimum zone, which corresponds to the seasonal thermocline (Fig. 15b).

20 Assuming as indicated in experiment 3 and 4 that $89 \%$ of the exported organic matter is respired within the seasonal thermocline it raises the question how slow must particles sink to be decomposed at such shallow water-depths? Using our equations from the numerical exercises as discussed before and considering a decay constant of 0.106 day $^{-1}$ a sinking speed of particles of about $8 \mathrm{~m} \mathrm{day}^{-1}$ would suffice to explain the respective decomposition in the Indian Ocean (Fig- 15 a). Such low sinking speed are within the range of those $\left(3-55 \mathrm{~m} \mathrm{day}^{-1}\right)$ determined at water-depth $<500 \mathrm{~m}$ in the subtropical Atlantic Ocean (McDonnell and Buesseler, 2012). Commonly used equations to parameterize organic carbon flux into the deep-sea (see e.g. Fig. 1) as well as results derived from comprehensive studies on carbon fluxes and respiration in the North Atlantic Ocean (Giering et al., 2014) support the assertion that the majority of organic matter is respired in the upper part of the water column. However, these equations show a continuously decreasing carbon flux but no clear distinction between the seasonal thermocline and the deep ocean (Fig. 1). This in turn is crucial considering that nutrients released beneath the seasonal thermocline are lost for the pelagic ecosystem.

Globally the depth and density of the seasonal thermocline varies and is deeper and denser in colder regions where upwelling and deep vertical mixing reduce the stratification. Vice versa, it is shallower and less dense in warm and stratified waters. The postulated accelerated respiration of organic matter at higher seawater temperatures (Iversen and Ploug, 2013; Marsay et 
Biogeosciences Discuss., https://doi.org/10.5194/bg-2017-317

Manuscript under review for journal Biogeosciences

Discussion started: 25 August 2017

(c) Author(s) 2017. CC BY 4.0 License.

al., 2015) could accordingly be a crucial factor ensuring the respiration of organic matter within the warmer and shallower seasonal thermocline of the ocean at lower latitudes. Furthermore, to reach this goal also sinking speeds of particles must be adjusted to the local density structure of the seasonal thermocline, which in turn explains the large variability of the density of the bulk components (Fig. 12). Nevertheless, the density of lithogenic matter, biogenic opal, and carbonate by far exceeds

5 the density of seawater even if one considers that it increases with increasing water-depth to values of up to approximately $1.05 \mathrm{~g} \mathrm{~cm}^{-3}$. Accordingly, tests discarded from foraminifera (e.g. Schiebel and Hemleben, 2000) as well as fecal pellets could reach sinking speeds of several hundred meters per day as mentioned before. Since this enhances the export of organic matter into the deep sea and lowers the productivity of pelagic ecosystems by favoring the removal of nutrients from the seasonal thermocline the formation of fast sinking particles is counterproductive. Hence, successful ecosystems should be characterized by low exports rates into the deep sea. The formation of TEP, which is lighter than seawater, is a possibility to counteract the formation of fast sinking particles and to sustain productivity by ensuring respiration of organic matter in the seasonal thermocline.

Nevertheless, even if only a small share of the export production is exported out of the seasonal thermocline into the deep sea $(1-6 \%$, Fig. 11a) it represents a loss of nutrients, which must be balanced over longer periods of time in order to

15 sustain pelagic ecosystems. The Antarctic mode water formation is the main source of nutrients for the tropical and subtropical seasonal thermocline and it is fed by upwelling of deep water at the Antarctic divergence (Pedlosky, 1990; Sarmiento et al., 2004; Stommel, 1979). In order to sustain productivity and the relatively constant carbon export as indicated by the trap data the loss of nutrients via the export of organic matter into the deep sea must be balanced by the mode water nutrient supply (Fig. 16).

20 If the fraction of the export production that reaches the deep sea increases and the associated loss of nutrients remains unbalanced by the mode water nutrient supply the nutrient concentrations in the seasonal thermocline decreases. Assuming a constant supply of subsurface water into the euphotic via upwelling and vertical mixing a decreasing nutrient concentration lowers nutrient inputs into the euphotic zone and thus the export production. Changes in ecosystem functions, which increase the formation of fast sinking particles due to e.g. the enhanced production of ballast material, the reduced formation of TEP,

25 and/or the production of fast sinking fecal pellets are accordingly contra-productive. On the other hand side an intensification of upwelling, which is associated with an enhanced mode water nutrient supply could balance enhanced losses of nutrients and sustain an enhanced organic carbon flux into the deep sea.

The functioning of such a bottom-up regulated system is extremely sensitive to climate changes. First of all, global warming might favor the export of particles out of the seasonal thermocline by lowering the seawater density and secondly increasing $\mathrm{CO}_{2}$ concentrations in the atmosphere could reduce the carbonate precipitation in surface waters (Pörtner et al., 2014). Numerical models designed to quantify impacts of increasing $\mathrm{CO}_{2}$ concentration in the atmosphere on the carbonate ballast effect reveal hardly any impact on the $\mathrm{CO}_{2}$ uptake of the biological carbon pumps even as the carbonate production in the open ocean was reduced by 50\% (Gangstø et al., 2011; Heinze, 2004). The opposing effects of the organic carbon and the calcium carbonate counter pump was believed to cause this, which means that the enhanced $\mathrm{CO}_{2}$ uptake by carrying $\mathrm{CO}_{2}$ 
Biogeosciences Discuss., https://doi.org/10.5194/bg-2017-317

Manuscript under review for journal Biogeosciences

Discussion started: 25 August 2017

(c) Author(s) 2017. CC BY 4.0 License.

into deeper waters was compensated by the enhanced formation of calcium carbonate. In river dominated systems the situation differs because the acidic freshwater reduces the carbonate production (Ittekkot et al., 1991; Rixen et al., 2006) and as discussed before lithogenic matter is the main ballast mineral determining the export out of the seasonal thermocline into the deep sea. In order to test the influence of the ballast effect on $\mathrm{CO}_{2}$ uptake of the ocean under the assumption that only fast

5 sinking particles reach the deep sea and slow ones are respired with the seasonal thermocline we developed a four-box model. Previous studies investigated the influenced of the ballast effect on $\mathrm{CO}_{2}$ uptake of the ocean by using the Martinequation (DeVries et al., 2012; Kwon et al., 2009).

\subsection{The Impact of the Ballast Effect on the $\mathrm{CO}_{2}$ Uptake of the Ocean}

The four-box model consists of an atmosphere, the euphotic zone, the seasonal thermocline, and the deep sea (Fig. 17). The

10 parameterization of Wanninkhof (1992) was used to the calculate air sea flux of $\mathrm{CO}_{2}$. Upwelling of water from the deep-sea and the seasonal thermocline supply nutrients into the seasonal thermocline and the euphotic zone and downwelling balances upwelling. For calculating up- and downwelling velocities between the deep sea and the seasonal thermocline a residence time of water within the deep sea of 1500 years was considered. A residence of 13 days was used to calculate the up- and downwelling velocities between the seasonal thermocline and the euphotic zone, which results in residence time of water within the seasonal thermocline of one year. A total carbon inventory of $3810^{18} \mathrm{gC}$ and $0.58910^{18} \mathrm{gC}$ was assumed for the ocean and the atmosphere (Ciais et al., 2013) and the concentration of total alkalinity and phosphate was adjusted to those obtained from the World Ocean Atlas (Tab. 3-4, Garcia et al., 2010; Goyet et al., 2000). If the model runs without considering the particle export the total dissolved inorganic carbon, the total alkalinity, and phosphate was equally distributed in the ocean and the $\mathrm{CO}_{2}$ concentration in the atmosphere amounts to $384 \mathrm{ppm}$. In a next step the export of phosphate incorporated into organic matter into and out of the seasonal thermocline was included. Phosphate was translated into carbon by using the Redfield ratio C/P ratio of 106, the exported production was adjusted to $10 \mathrm{Pg} \mathrm{C}$ year ${ }^{-1}$, and $10 \%$ of the export production was assumed to be exported out the seasonal thermocline by the formation of fast sinking particles (Tab. 4 - Experiment 1). The organic to carbonate carbon ratio was set to 0.7 as seen in the sediment trap data (Klaas and Archer, 2002; Rixen et al., 2009). The resulting concentration of phosphate agreed to those obtained by Garcia (Garcia et al., 2010 ) and the total alkalinity (TA) was selected in order to obtain an atmospheric $\mathrm{CO}_{2}$ concentration of 280 ppm equaling those in the preindustrial atmosphere. However, the phosphate concentration in the euphotic zone was higher in our model as in the World Ocean Atlas, which first of all reflects an overestimation of preformed nutrients. As mentioned before, these nutrients are formed when the lack of light prevents their utilization in winter at the sites of deep and mode water formation. Due to the scarcity of wintertime data from these regions the nutrient concentration in the WOA might also be 30 underestimates. However, more complex box models and general circulation models produces phosphate concentration of 1.4 and $0.2 \mu \mathrm{M}$ in high and low latitudes with a mean of about $0.4 \mu \mathrm{M}$ at a $\mathrm{CO}_{2}$ concentration of $270-280 \mathrm{ppm}$ (Archer et al., 2000). Within these models decreasing phosphate concentrations are associated with decreasing atmospheric $\mathrm{CO}_{2}$ 
Biogeosciences Discuss., https://doi.org/10.5194/bg-2017-317

Manuscript under review for journal Biogeosciences

Discussion started: 25 August 2017

(c) Author(s) 2017. CC BY 4.0 License.

concentrations as in our model, which was designed to study the influence of the ballast effect on the $\mathrm{CO}_{2}$ uptake of the ocean (Tab. 4).

Therefore, we first assumed that an enhanced lithogenic matter supply increases the ballast effect and enhances the fraction of organic matter, which is exported into the deep sea (Tab. 4 - Experiment 2). The rain ratio remained constant and the

5 fraction of the export production, which reaches the deep sea is increased from 10 to $20 \%$. The $\mathrm{CO}_{2}$ concentration in the atmosphere decreased by $35 \mathrm{ppm}$ from 280 (experiment 1) to $245 \mathrm{ppm}$ (experiment 2) and the associated enhanced storage of carbon and nutrients in the deep sea lowered the export production from 10.67 to $7.65 \mathrm{PgC}_{\text {year }}{ }^{-1}$.

In the following experiment we assumed that an enhanced carbonate production strengthened the ballast effect and raised the rain ratios from 0.7 to 1.12 (Tab. 4 - Experiment 3). The organic carbon flux remained constant but the $\mathrm{CO}_{2}$ concentration

10 increased form 245 to $280 \mathrm{ppm}$ and equaled those obtained without considering an enhanced ballast effect. This result agrees to those results obtained from global ocean general circulation models (Gangstø et al., 2011; Heinze, 2004) and meets the expectation that the ballast effect increases the export of nutrients into the deep ocean. The effect on the $\mathrm{CO}_{2}$ concentration depends additionally on the rain ratio and decreases if the rain ratio increases.

During the last two experiments we tested the extent to which the preformed nutrient concentration determines the influence

15 of an enhanced lithogenic matter supply on the $\mathrm{CO}_{2}$ uptake of the ocean. If one assumes that phytoplankton consumes all nutrients in the surface water and exports it as organic matter into the deep sea the export production increases from $10.67 \mathrm{Pg}$ $\mathrm{C}$ year ${ }^{-1}$ (Tab. 4 - Experiment 1) to $26.84 \mathrm{Pg} \mathrm{C}$ year $^{-1}$ (Tab. 4 - Experiment 4). The $\mathrm{CO}_{2}$ concentration in turn decreases from 280 to $174 \mathrm{ppm}$ suggesting that a reduced formation of preformed nutrients could strongly reduce the atmospheric $\mathrm{CO}_{2}$ concentration as shown also in other models studies (Archer et al., 2000; Ito and Follows, 2005). However, the assumption that all nutrients are used is unrealistic and would probably cause anoxia in the real ocean. Nevertheless, such a numerical exercise its quite interesting because it provides the possibility to study the influence of the ballast effect on the $\mathrm{CO}_{2}$ uptake of the ocean in the absence of preformed nutrients (Tab. 4 - Experiment 5). As in experiment 2 we just increased the fraction of export production to the deep sea from 10 to $20 \%$. Consequences were a reduced export production but in contrast to experiment 2 the $\mathrm{CO}_{2}$ concentration equaled $174 \mathrm{ppm}$ those of experiment 4. Accordingly, the ballast effect did not affect the atmosphere $\mathrm{CO}_{2}$ concentration in the absence of preformed nutrients, which in turn means that its impact on the $\mathrm{CO}_{2}$ concentration depends on the preformed nutrient concentrations.

This could be explained if one imagines that in the absence of preformed nutrients all nutrients are regenerated nutrients, which means they are attached to $\mathrm{CO}_{2}$. The total amount of stored $\mathrm{CO}_{2}$ results from the product of the nutrient inventory and $\mathrm{C} / \mathrm{P}$ ratio of 106 . This maximum storing capacity cannot be exceeded and thus eliminates the influence of the ballast effect on the $\mathrm{CO}_{2}$ uptake.

Nevertheless, the ballast effect enhances the nutrient storage in the deep ocean and lowers nutrient concentrations in the upper ocean. In the presence of preformed nutrients this increases the residence time of regenerated nutrients in the deep ocean and reduces the formation of preformed nutrients in the surface waters. This in turn increases the $\mathrm{CO}_{2}$ uptake of the 
Biogeosciences Discuss., https://doi.org/10.5194/bg-2017-317

Manuscript under review for journal Biogeosciences

Discussion started: 25 August 2017

(c) Author(s) 2017. CC BY 4.0 License.

ocean. The more preformed nutrients are transferred into regenerated nutrients and exported as organic matter into the deep ocean the stronger is the influence of the ballast effect on the $\mathrm{CO}_{2}$ uptake.

A similar result was obtained by DeVries et al. (2012). These authors used an ocean circulation model in which the organic flux was described by the equation introduced by Martin at al. (1987). However, they introduced the term sequestration

5 efficiency, which similar to our approach defines the proportion of export production out of the seasonal thermocline into the deep sea. The associated $\mathrm{CO}_{2}$ uptake efficiency in turn was strongly influenced by the availability of preformed nutrients indicating as in our exercise that the ballast effect influences the $\mathrm{CO}_{2}$ uptake via its influence on the preformed nutrient concentrations. The more preformed nutrients the stronger the influences of the ballast effect on the $\mathrm{CO}_{2}$ uptake of the organic carbon pump. This implies that the ballast effect is strongest at high latitudes in the regions where the preformed nutrients are formed whereas at lower latitudes where the euphotic zone is nutrient depleted the ballast effect appears to be of lower importance for the $\mathrm{CO}_{2}$ uptake of the ocean. Accordingly enhanced aeolian dust input, was assumed to increase the $\mathrm{CO}_{2}$ uptake of the ocean during the glacial periods by fertilizing the Southern Ocean with iron and supplying lithogenic ballast material (Falkowski et al., 1998; Ittekkot, 1993).

Quantitatively aeolian dust input is with an average of 475 Mill. $t$ year $^{-1}$ almost negligible compared to a river discharge of 14030 Mill t year ${ }^{-1}$ (Mahowald et al., 2005; Syvitski et al., 2005). However, rivers supply lithogenic matter mainly in the tropics and warmer temperate regions ( $>75 \%$ of the global discharge) (Syvitski et al., 2005), which restricts their impact on the $\mathrm{CO}_{2}$ uptake of the organic carbon pump but not their role in the global carbon cycle. Since it enhances the organic carbon export and favors burial of organic matter in marine sediments (Keil, 2011; Keil and Hedges, 1993) it controls the life-time of $\mathrm{CO}_{2}$ in the climate systems. Accordingly the riverine lithogenic matter supply plays an important role in the long-term carbon cycle and since it increases not only the supply of organic matter but also its preservation within sediments, $>80 \%$ of the organic carbon burial occurs in river-dominated systems (Hedges and Keil, 1995).

\section{Conclusion}

Our data showed that the organic carbon flux into the deep sea in the higher productive upwelling systems could be as high as in low productive systems influenced by river discharges. Within the river-influenced regions the ballast effect exerted by the supply of lithogenic matter from land mainly controls the organic carbon flux whereas carbonate produced by marine organisms appear to be the main ballast material in the high productive and more marine dominated regions. The flux of carbonate tends to increase with an increasing exports production due to which the relative importance of productivity and the ballast effect on the organic flux into the deep sea is difficult to quantify. Since the export of organic matter into the deep sea represents a loss of nutrients the mode water nutrient supply balances this losses in order to sustain the productivity of pelagic ecosystems. The ballast effect increases the $\mathrm{CO}_{2}$ uptake of the organic carbon by enhancing the removal of preformed nutrients from the euphotic zone. For that reason, it appears to be most efficient at high latitudes and less effective at lower latitudes where the euphotic zone is nutrient depleted. Contrary to the supply of lithogenic matter the carbonate 
Biogeosciences Discuss., https://doi.org/10.5194/bg-2017-317

Manuscript under review for journal Biogeosciences

Discussion started: 25 August 2017

(C) Author(s) 2017. CC BY 4.0 License.

precipitation reduces the influence of the ballast effect on $\mathrm{CO}_{2}$ uptake. In the river-influenced Indian Ocean the influence of lithogenic matter supply on the $\mathrm{CO}_{2}$ of the organic carbon pump might be much lower as those of aeolian dust inputs into the ocean at higher latitudes. However, it enhances the export of organic matter into the deep sea and favors the sedimentation of organic carbon. Since $>80 \%$ of the organic carbon burial occurs in rivers-dominated systems the lithogenic ballast strongly

5 influences the Earth's climate on geological time scales.

\section{Acknowledgment}

First of all we would like to thank all the scientists, technicians, officers and their crews of the numerous research vessels used during our studies in the Indian Ocean. We would specifically like to express our gratitude to the Federal German Ministry for Education, Science, Research and Technology (BMBF, Bonn ref. no. 03F0463A), the Council of Scientific and 10 Industrial Research (CSIR, New Delhi), the Ministry of Earth Sciences (MOES, New Delhi), and the Agency for the Assessment and Application of Technology (BPPT), Jakarta, Indonesia for financial support. P. Wessels and W.H.F Smith are acknowledged for providing the generic mapping tools (GMT).

\section{References}

Alldredge, A. L. and Gotschalk, C.: In situ setting behavior of marine snow, Limnology and Oceanography, 33, 339-351, 1988.

15 Alldredge, A. L. and McGillivary, P.: The attachment probabilities of marine snow and their implications for particle coagulation in the ocean, Deep Sea Research, 38, 431-443, 1991.

Andersson, A., Fennig, K., Klepp, C., Bakan, S., Grassl, H., and Schulz, J.: The Hamburg Ocean Atmosphere Parameters and Fluxes from Satellite Data - HOAPS-3, Earth Syst. Sci. Data, 2, 215-234, 2010.

Antoine, D., André, J.-M., and Morel, A.: Oceanic primary production - 2. Estimation at global scale from satellite (coastal zone color scanner) chlorophyll, Global Biogeochemical Cycles, 10, 57-69, 1996.

Archer, D. E., Eshel, G., Winguth, A., Broecker, W., Pierrehumbert, R., Tobis, M., and Jacob, R.: Atmospheric $p \mathrm{CO}_{2}$ sensitivity to the biological pump in the ocean, Global Biogeochemical Cycles, 14, 1219-1230, 2000.

Armstrong, R. A., Lee, C., Hedges, J. I., Honjo, S., and Wakeham, S.: A new, mechanistic model for organic carbon fluxes in the ocean: based on the quantitative association of POC with ballast minerals, Deep Sea Research, 49, 219 - 236, 2002.

25 Asper, V. L.: Measuring the flux and sinking speed of marine snow aggregates, Deep-Sea Research, 34, 1-17, 1987.

Avnimelech, Y., Troeger, B. W., and Reed, L. W.: Mutual Flocculation of Algae and Clay: Evidence and Implications, Science, 216, 63$65,1982$.

Azetsu-Scott, Kumiko, and Passow, U.: Ascending marine particles: Significance of transparent exopolymer particles (TEP) in the upper ocean, Limnology Oceanography, 49, 741 - 748, 2004.

30 Banse, K.: New views on the degradation and disposition of organic particles as collected by sediment traps in the open sea, Deep Sea Research, 37, 1177-1195, 1990.

Banse, K. and English, D. C.: Geographical differences in seasonality of CZCS-derived phytoplankton pigment in the Arabian Sea for 1978-1986, Deep Sea Research Part II: Topical Studies in Oceanography, 47, 1623-1677, 2000.

Banse, K. and English, D. C.: Seasonality of coastal zone color scanner phytoplankton pigment in the offshore oceans, Journal of Geophysical Research, 99, 7323-7345, 1994.

Bauer, S., Hitchcock, G. L., and Olson, D. B.: Influence of monsoonally-forced Ekman dynamics upon surface layer depth and plankton biomass distribution in the Arabian Sea, Deep Sea Research, 38, 531-553, 1991.

Behrenfeld, M. J. and Falkowski, P. G.: A consumer's guide to phytoplankton primary productivity models, Limnology and Oceanography, 42, 1479-1491, 1997a.

40 Behrenfeld, M. J. and Falkowski, P. G.: Photosynthetic rates derived from satellite-based chlorophyll concentration, Limnology and Oceanography, 42, 1-20, 1997 b. 
Biogeosciences Discuss., https://doi.org/10.5194/bg-2017-317

Manuscript under review for journal Biogeosciences

Discussion started: 25 August 2017

(c) Author(s) 2017. CC BY 4.0 License.

Berelson, W. M.: Particle settling rates increase with depth in the ocean, Deep Sea Research Part II: Topical Studies in Oceanography, 49, $237-251,2001$

Berger, W. H., Fischer, K., Lai, C., and Wu, G.: Ocean Carbon Flux: Global Maps of Primary Production and Export Production. In: Biogeochemical Cycling and Fluxes Between the Deep Euphotic Zone and Other Oceanic Realms, Agegian, C. R. (Ed.), NOAA National Undersea Research Program, Res Rpt., 1988.

Bishop, J. K. B.: Regional Extremes in Particulate Matter Composition and Flux: Effects on the Chemistry of the Ocean Interior. In: Productivity of the Ocean: Present and Past, Berger, W. H., Smetacek, V. S., and Wefer, G. (Eds.), John Wiley \& Sons Limited, Dahlem, 1989

Bopp, L., Resplandy, L., Orr, J. C., Doney, S. C., Dunne, J. P., Gehlen, M., Halloran, P., Heinze, C., Ilyina, T., Séférian, R., Tjiputra, J., and Vichi, M.: Multiple stressors of ocean ecosystems in the 21st century: projections with CMIP5 models, Biogeosciences, 10, 6225-6245, 2013.

Ciais, P., Sabine, C., Bala, G., Bopp, L., Brovkin, V., Canadell, J., Chhabra, A., DeFries, R., Galloway, J., Heimann, M., Jones, C., Le Quéré, C., Myneni, R. B., Piao, S., and Thornton, P.: Carbon and Other Biogeochemical Cycles. In: Climate Change 2013: The Physical Science Basis. Contribution of Working Group I to the Fifth Assessment Report of the Intergovernmental Panel on Climate Change, Stocker, T. F., Qin, D., Plattner, G.-K., Tignor, M., Allen, S. K., Boschung, J., Nauels, A., Xia, Y., Bex, V., and Midgley, P. M. (Eds.), Cambridge University Press, Cambridge, United Kingdom and New York, NY, USA, 2013.

Csögör, Z., Melgar, D., Schmidt, K., and Posten, C.: Production and particle characterization of the frustules of Cyclotella cryptica in comparison with siliceous earth, Journal of Biotechnology, 70, 71-75, 1999.

de Boyer Montégut, C., Madec, G., Fischer, A. S., Lazar, A., and Iudicone, D.: Mixed layer depth over the global ocean: An examination of profile data and a profile-based climatology, Journal of Geophysical Research: Oceans, 109, n/a-n/a, 2004.

De La Rocha, C. L., Nowald, N., and Passow, U.: Interactions between diatom aggregates, minerals, particulate organic carbon, and dissolved organic matter: Further implications for the ballast hypothesis, Global Biogeochemical Cycles, 22, n/a-n/a, 2008.

del Giorgio, P. A. and Duarte, C. M.: Respiration in the open ocean, Nature, 420, 379-384, 2002.

DeMaster, D. J.: 7.04 - The Diagenesis of Biogenic Silica: Chemical Transformations Occurring in the Water Column, Seabed, and Crust A2 - Turekian, Heinrich D. HollandKarl K. In: Treatise on Geochemistry, Pergamon, Oxford, 2003.

Deng, W., Monks, L., and Neuer, S.: Effects of clay minerals on the aggregation and subsequent settling of marine Synechococcus, Limnology and Oceanography, 60, 805-816, 2015.

DeVries, T., Primeau, F., and Deutsch, C.: The sequestration efficiency of the biological pump, Geophysical Research Letters, 39, L13601, 2012.

30 Durkin, C. A., Estapa, M. L., and Buesseler, K. O.: Observations of carbon export by small sinking particles in the upper mesopelagic, Marine Chemistry, 175, 72-81, 2015

DWD: ftp://ftp-anon.dwd.de/pub/data/gpcc/html/monitoring download.htm2010

Engel, A., Szlosek, J., Abramson, L., Liu, Z., and Lee, C.: Investigating the effect of ballasting by CaCO3 in Emiliania huxleyi: I. Formation, settling velocities and physical properties of aggregates, Deep Sea Research Part II: Topical Studies in Oceanography, 56, 1396-1407, 2009.

Eppley, R. W. and Peterson, B. J.: Particulate organic matter flux and planktonic new production in the deep ocean, Nature, 282, 677-680, 1979.

Falkowski, P. G., Barber, R. T., and Smetacek, V.: Biogeochemical Controls and Feedbacks on Ocean Primary Production, Science, 281, 200-206, 1998

40 Findlater, J.: Observational Aspects of the Low-level Cross-equatorial Jet Stream of the Western Indian Ocean, Pageoph., 115, 1251-1262, 1977.

Fogg, G. E.: The Production of Extracellular Nitrogenous Substances by a Blue-Green Alga, Proceedings of the Royal Society of London B: Biological Sciences, 139, 372-397, 1952.

Fogg, G. E., Nalewajko, C., and Watt, W. D.: Extracellular Products of Phytoplankton Photosynthesis, Proceedings of the Royal Society of London B: Biological Sciences, 162, 517-534, 1965.

Francois, R., Honjo, S., Krishfield, R., and Manganini, S.: Factors controlling the flux of organic carbon to the bathypelagic zone of the ocean, Global Biogeochemical Cycles, 16, 34-31 - 34-20, 2002.

Gadgil, S., Rajeevan, M., and Francis, P. A.: Monsoon variability: Links to major oscillations over the equatorial Pacific and Indian oceans, Current science, 93, 182-194, 2007.

50 Gangstø, R., Joos, F., and Gehlen, M.: Sensitivity of pelagic calcification to ocean acidification, Biogeosciences, 8, 433-458, 2011.

Garcia, H. E., Locarnini, R. A., Boyer, T. P., Antonov, J. I., Zweng, M. M., Baranova, O. K., and Johnson, D. R.: World Ocean Atlas 2009. In: NOAA Atlas NESDIS 71, Levitus, S. (Ed.), U.S. Government Printing Office, Washington, D.C., 2010.

Gaye, B., Nagel, B., Dähnke, K., Rixen, T., and Emeis, K.-C.: Evidence of parallel denitrification and nitrite oxidation in the ODZ of the Arabian Sea from paired stable isotopes of nitrate and nitrite, Global Biogeochemical Cycles, doi: 10.1002/2011gb004115, 2013. $2011 \mathrm{~GB} 004115,2013$. 
Biogeosciences Discuss., https://doi.org/10.5194/bg-2017-317

Manuscript under review for journal Biogeosciences

Discussion started: 25 August 2017

(c) Author(s) 2017. CC BY 4.0 License.

Giering, S. L. C., Sanders, R., Lampitt, R. S., Anderson, T. R., Tamburini, C., Boutrif, M., Zubkov, M. V., Marsay, C. M., Henson, S. A., Saw, K., Cook, K., and Mayor, D. J.: Reconciliation of the carbon budget in the ocean/'s twilight zone, Nature, 507, 480-483, 2014.

Glibert, P. M. and Bronk, D. A.: Release of Dissolved Organic Nitrogen by Marine Diazotrophic Cyanobacteria, Trichodesmium spp, Applied and Environmental Microbiology, 60, 3996-4000, 1994.

Goyet, C., Healy, R., and Ryan, J. P.: Global distribution of total inorganic carbon and total alkalinity below the deepest winter mixed

layer depths, ORNL/CDIAC-127, Carbon Dioxide Inf. Anal. Cent., Oak Ridge Natl. Lab., U.S. Dep. of Energy, Oak Ridge, Tenn., 2000.

Guidi, L., Stemmann, L., Jackson, G. A., Ibanez, F., Claustre, H., Legendre, L., Picheral, M., and Gorskya, G.: Effects of phytoplankton community on production, size, and export of large aggregates: A world-ocean analysis, Limnology and Oceanography, 54, 1951-1963, 2009.

Haake, B. and Ittekkot, V.: Die Wind-getriebene "biologische Pumpe" und der Kohlenstoffentzug im Ozean, Naturwissenschaften, 77, 75$79,1990$.

Haake, B., Ittekkot, V., Rixen, T., Ramaswamy, V., Nair, R. R., and Curry, W. B.: Seasonality and interannual variability of particle fluxes to the deep Arabian Sea, Deep Sea Research I, 40, 1323-1344, 1993.

15 Haas, A. F. and Wild, C.: Composition analysis of organic matter released by cosmopolitan coral reef-associated green algae, Aquatic Biology, 10, 131-138, 2010.

Hamm, C. E.: Interactive aggregation and sedimentation of diatoms and clay-sized lithogenic material, Limnology and Oceanography, 47, 1790-1795, 2002.

Hansell, D. A.: Recalcitrant Dissolved Organic Carbon Fractions, Annual Review of Marine Science, 5, 421-445, 2013.

20 Hansell, D. A., Carlson, C. A., Repeta, D. J., and Schlitzer, R.: Dissolved organic matter in the ocean: A controversy stimulates new insights, Oceanography, 22, 202-211, 2009.

Hedges, J. I. and Keil, R. G.: Sedimentary organic matter preservation: an assessment and speculative synthesis, Marine Chemistry, 49, $81-115,1995$

Heinze, C.: Simulating oceanic $\mathrm{CaCO}_{3}$ export production in the greenhouse, Geophysical Research Letters, 31, doi:10.1029/2004GL020613, 2004.

Heinze, C., Maier-Reimer, E., and Winn, K.: Glacial $\mathrm{pCO}_{2}$ Reduction by the World Ocean: Experiments with the Hamburg Carbon Cycle Model, Paleoceanography, 6, 395-430, 1991.

Hendiarti, N., Siegel, H., and Ohde, T.: Investigation of different coastal processes in Indonesian water using SeaWiFS data., Deep Sea Research, 51, 85-97, 2004.

30 Honjo, S.: Coccoliths: Production, Transportation and Sedimentation, Marine Micropaleontology, 1, 65-79, 1976.

Honjo, S.: Seasonality and Interaction of Biogenic and Lithogenic Particulate Flux at the Panama Basin, Science, 218, 883-884, 1982.

Honjo, S., Dymond, J., Prell, W., and Ittekkot, V.: Monsoon-controlled export fluxes to the interior of the Arabian Sea, Deep Sea Research II, 46, 1859-1902, 1999.

Honjo, S., Manganini, S. J., Krishfield, R. A., and Francois, R.: Particulate organic carbon fluxes to the ocean interior and factors controlling the biological pump: A synthesis of global sediment trap programs since 1983, Progress in Oceanography, 76, 217285,2008 .

Ito, T. and Follows, M. J.: Preformed phosphate, soft tissue pump and atmospheric $\mathrm{CO}_{2}$, Journal of Marine Research, 63, 813 - 839, 2005.

Ittekkot, V.: The abiotically driven biological pump in the ocean and short-term fluctuations in atmospheric $\mathrm{CO}_{2}$ contents, Global and Planetary Change, 8, 17-25, 1993.

40 Ittekkot, V. and Haake, B.: The Terrestrial Link in the Removal of Organic Carbon in the Sea. In: Factes of Modern Biogeochemistry, Ittekkot, V., Kempe, S., Michaelis, W., and Spitzy, A. (Eds.), Springer Verlag, Berlin, Heidelberg, New York, 1990.

Ittekkot, V., Haake, B., Bartsch, M., Nair, R. R., and Ramaswamy, V.: Organic carbon removal in the sea: the continental connection. In: Upwelling Systems: Evolution Since the Early Miocene, Summerhayes, C. P., Prell, W. L., and Emeis, K. C. (Eds.), Geological Society Special Publication, 1992.

45 Ittekkot, V., Nair, R. R., Honjo, S., Ramaswamy, V., Bartsch, M., Manganini, S., and Desai, B. N.: Enhanced particle fluxes in Bay of Bengal induced by injection of fresh water, Nature, 351, 385-387, 1991.

Iversen, M. H., Nowald, N., Ploug, H., Jackson, G. A., and Fischer, G.: High resolution profiles of vertical particulate organic matter export off Cape Blanc, Mauritania: Degradation processes and ballasting effects, Deep Sea Research Part I: Oceanographic Research Papers, 57, 771-784, 2010.

50 Iversen, M. H. and Ploug, H.: Ballast minerals and the sinking carbon flux in the ocean: carbon-specific respiration rates and sinking velocity of marine snow aggregates, Biogeosciences, 7, 2613-2624, 2010.

Iversen, M. H. and Ploug, H.: Temperature effects on carbon-specific respiration rate and sinking velocity of diatom aggregates \&ndash; potential implications for deep ocean export processes, Biogeosciences, 10, 4073-4085, 2013.

Iversen, M. H. and Robert, M. L.: Ballasting effects of smectite on aggregate formation and export from a natural plankton community, Marine Chemistry, 175, 18-27, 2015.

Keil, R. G.: Terrestrial influences on carbon burial at sea, Proceedings of the National Academy of Sciences, 108, 9729-9730, 2011. 
Biogeosciences Discuss., https://doi.org/10.5194/bg-2017-317

Manuscript under review for journal Biogeosciences

Discussion started: 25 August 2017

(c) Author(s) 2017. CC BY 4.0 License.

Keil, R. G. and Hedges, J. I.: Sorption of organic matter to mineral surfaces and the preservation of organic matter in coastal marine sediments, Chemical Geology, 107, 385-388, 1993.

Klaas, C. and Archer, D. E.: Association of sinking organic matter with various types of mineral ballast in the deep sea: Implications for the rain ratio., Global Biogeochemical Cycles, 16, doi:10.1029/2001GB001765, 2002.

5 Koning, E., Brummer, G.-J., Van Raaphorst, W., Van Bennekom, J., Helder, W., and Van Iperen, J.: Settling, dissolution and burial of biogenic silica in the sediments off Somalia (northwestern Indian Ocean), Deep Sea Research Part II: Topical Studies in Oceanography, 44, 1341-1360, 1997.

Kranck, K.: Flocculation of Suspended Sediment in the Sea, Nature, 246, 348-350, 1973.

Kwon, E. Y., Primeau, F., and Sarmiento, J. L.: The impact of remineralization depth on the air-sea carbon balance, Nature Geosci, 2, 630$635,2009$.

Lal, D. and Lerman, A.: Size spectra of biogenic particles in ocean water and sediments, Journal of Geophysical Research, 80, 423-430, 1975 .

Laws, E. A., Falkowski, P. G., Smith, W. O., Ducklow, H., and McCarthy, J. J.: Temperature effects on export production in the open ocean, Global Biogeochemical Cycles, 14, 1231-1246, 2000.

15 Lee, C., Murray, D. W., Barber, R. T., Buesseler, K. O., Dymond, J., Hedges, J. I., Honjo, S., Manganini, S. J., and Marra, J.: Particulate organic carbon fluxes: compilation of results from the 1995 US JGOFS Arabian Sea Process Study, Deep Sea Research II, 45, 2489-2501, 1998 .

Lee, C., Wakeham, S. G., and Arnosti, C.: Particulate organic matter in the sea: the composition conundrum, Ambio, 33, 565-575, 2004.

Logan, B. E. and Hunt, J. R.: Advantages to microbes of growth in permeable aggregates in marine systems1, Limnology and Oceanography, 32, 1034-1048, 1987.

Luther, M. E. and O'Brien, J. J.: Variability in Upwelling Fields in the Northwestern Indian Ocean - 1. Model Experiments for the Past 18,000 Years, Paleoceanography, 5, 433-445, 1990.

Lutz, M., Dunbar, R., and Caldeira, K.: Regional variability in the vertical flux of particulate organic carbon in the ocean interior, Global Biogeochemical Cycles, 16, 11-11-11-15, 2002.

25 Lutz, M. J., Caldeira, K., Dunbar, R. B., and Behrenfeld, M. J.: Seasonal rhythms of net primary production and particulate organic carbon flux to depth describe the efficiency of biological pump in the global ocean, Journal of Geophysical Research: Oceans, 112, C10011, 2007.

Mahowald, N. M., Baker, A. R., Bergametti, G., Brooks, N., Duce, R. A., Jickells, T. D., Kubilay, N., Prospero, J. M., and Tegen, I.: Atmospheric global dust cycle and iron inputs to the ocean, Global Biogeochemical Cycles, 19, n/a-n/a, 2005.

30 Marsay, C. M., Sanders, R. J., Henson, S. A., Pabortsava, K., Achterberg, E. P., and Lampitt, R. S.: Attenuation of sinking particulate organic carbon flux through the mesopelagic ocean, Proceedings of the National Academy of Sciences of the United States of America, 112, 1089-1094, 2015.

Martin, J. H., Knauer, G. A., Karl, D. M., and Broenkow, W. W.: VERTEX: carbon cycling in the northeast Pacific, Deep Sea Research, 34, 267-285, 1987.

35 McCave, I. N.: Size Spectra and aggregation of suspended particles in the deep ocean, Deep Sea Research, 31, 329-352, 1984.

McCave, I. N.: Vertical flux of particles in the ocean, Deep Sea Research, 22, 491-502, 1975.

McClain, C. R., Feldman, G. C., and Hooker, S. B.: An overview of the SeaWiFS project and strategies for producing a climate research quality global ocean bio-optical time series, Deep Sea Research Part II: Topical Studies in Oceanography, 51, 5-42, 2004.

McDonnell, A. M. P., Boyd, P. W., and Buesseler, K. O.: Effects of sinking velocities and microbial respiration rates on the attenuation of particulate carbon fluxes through the mesopelagic zone, Global Biogeochemical Cycles, 29, 175-193, 2015.

McDonnell, A. M. P. and Buesseler, K. O.: A new method for the estimation of sinking particle fluxes from measurements of the particle size distribution, average sinking velocity, and carbon content, Limnology and Oceanography: Methods, 10, 329-346, 2012.

Michaels, A. F. and Silver, M. W.: Primary production, sinking fluxes and the microbial food web, Deep Sea Research Part A. Oceanographic Research Papers, 35, 473-490, 1988.

45 Miklasz, K. A. and Denny, M. W.: Diatom sinkings speeds: Improved predictions and insight from a modified Stokes' law, Limnology and Oceanography, 55, 2513-2525, 2010.

Mohtadi, M., Steinke, S., Groeneveld, J., Fink, H., G., Rixen, T., Hebbeln, D., Donner, B., and Herunadi, B.: Low-latitude control on seasonal and interannual changes in planktonic foraminiferal flux and shell geochemistry off south Java: A sediment trap study, Paleoceanography, 24, PA1201, 2009.

50 Mottana, A., Crespi, R., and Liborio, G.: Simon \& Schuster's guide to rocks \& minerals, Simon and Schuster, New York, 1978.

Nair, R. R., Ittekkot, V., Manganini, S. J., Ramaswamy, V., Haake, B., Degens, E. T., Desai, B. N., and Honjo, S.: Increased particle flux to the deep ocean related to monsoons, Nature, 338, 749-751, 1989.

Naqvi, W. A.: Geographical extent of denitrification in the Arabian Sea in relation to some physical processes, Oceanologica Acta, 14, 281-290, 1991.

55 Nielsen, E. S.: Measurement of the Production of Organic Matter in the Sea by means of Carbon-14, Nature, 167, 684-685, 1951.

O'Malley, R.: http://www.science.oregonstate.edu/ocean.productivity/, last access: 2015, 2015. 
Biogeosciences Discuss., https://doi.org/10.5194/bg-2017-317

Manuscript under review for journal Biogeosciences

Discussion started: 25 August 2017

(c) Author(s) 2017. CC BY 4.0 License.

Osipov, V. I.: Density of clay minerals, Soil Mechanics and Foundation Engineering, 48, 231-240, 2012

Osterberg, C., Small, L., and Hubbard, L.: Radioactivity in Large Marine Plankton as a Function of Surface Area, Nature, 197, 883-884, 1963.

Pedlosky, J.: The Dynamics of the Oceanic Subtropical Gyres, Science, 248, 316, 1990.

5 Ploug, H. and Grossart, H.-P.: Bacterial growth and grazing on diatom aggregates: Respiratory carbon turnover as a function of aggregate size and sinking velocity, Limnology and Oceanography, 45, 1467-1475, 2000.

Pörtner, H.-O., Karl, D. M., Boyd, P. W., Cheung, W. W. L., Lluch-Cota, S. E., Nojiri, Y., Schmidt, D. N., and Zavialov, P. O.: Ocean systems. In: Climate Change 2014: Impacts, Adaptation, and Vulnerability. Part A: Global and Sectoral Aspects. Contribution of Working Group II to the Fifth Assessment Report of the Intergovernmental Panel on Climate Change, Field, C. B., Barros, V. R., Dokken, D. J., Mach, K. J., Mastrandrea, M. D., Bilir, T. E., Chatterjee, M., Ebi, K. L., Estrada, Y. O., Genova, R. C., Girma, B., Kissel, E. S., Levy, A. N., MacCracken, S., Mastrandrea, P. R., and White, L. L. (Eds.), Cambridge University Press, Cambridge, United Kingdom and NewYork, NY, USA, 2014.

Quadfasel, D. and Cresswell, G. R.: A Note on the Seasonal Variability of the South Java Current, Journal of Geophysical Research, 97, 3685-3688, 1992.

15 Quillin, M. L. and Matthews, B. W.: Accurate calculation of the density of proteins, Acta Crystallographica Section D, 56, 791-794, 2000.

Ramage, C. S.: Monsoon Meteorology, Academic Press, New York, London, 1971.

Ramaswamy, V., Nair, R. R., Manganini, S., Haake, B., and Ittekkot, V.: Lithogenic fluxes to the deep Arabian Sea measured by sediment traps, Deep Sea Research, 38, 169-184, 1991.

Ramaswamy, V., Vijay Kumar, B., Parthiban, G., Ittekkot, V., and Nair, R. R.: Lithogenic fluxes in the Bay of Bengal measured by sediment traps, Deep Sea Research Part I: Oceanographic Research Papers, 44, 793-810, 1997.

Rex, R. W. and Goldberg, E. D.: Quartz Contents of Pelagic Sediments of the Pacific Ocean1, Tellus, 10, 153-159, 1958.

Rixen, T., Baum, A., Gaye, B., and Nagel, B.: Seasonal and interannual variations in the nitrogen cycle in the Arabian Sea, Biogeosciences, 11, 5733-5747, 2014

Rixen, T., Guptha, M. V. S., and Ittekkot, V.: Sedimentation. In: Report of the Indian Ocean Synthesis Group on the Arabian Sea Process Study, Watts, L., Burkill, P. H., and Smith, S. (Eds.), JGOFS International Project Office, Bergen, 2002.

Rixen, T., Haake, B., and Ittekkot, V.: Sedimentation in the western Arabian Sea: the role of coastal and open-ocean upwelling, Deep Sea Research II, 47, 2155-2178, 2000a.

Rixen, T., Haake, B., Ittekkot, V., Guptha, M. V. S., Nair, R. R., and Schlüssel, P.: Coupling between SW monsoon-related surface and deep ocean processes as discerned from continuous particle flux meausurements and correlated satellite data, Journal of Geophysical Research, 101, 28,569-528,582, 1996.

Rixen, T., Ittekkot, V., Haake-Gaye, B., and Schäfer, P.: The influence of the SW monsoon on the deep-sea organic carbon cycle in the Holocene, Deep Sea Research II, 47, 2629-2651, 2000b.

Rixen, T., Ittekkot, V., Herundi, B., Wetzel, P., Maier-Reimer, E., and Gaye-Haake, B.: ENSO-driven carbon see saw in the Indo-Pacific, Journal of Geophysical Research Letters, 33, doi:10.1029/2005GL024965, 2006.

35 Rixen, T., Ittekkot, V., Herundi, B., Wetzel, P., Maier-Reimer, E., and Gaye-Haake, B.: ENSO-driven changes in carbon fluxes to the deep sea off south Java, Paris2005, 28.

Rixen, T., Ramaswamy, V., Gaye, B., Herunadi, B., Maier-Reimer, E., Bange, H. W., and Ittekkot, V.: Monsoonal and ENSO Impacts on Export Fluxes and the Biological Pump in the Indian Ocean In: Indian Ocean Biogeochemical Processes and Ecological Variability, Hood, R. R., Wiggert, J. D., Naqvi, S. W. A., Smith, S., and Brink, K. (Eds.), 185, AGU, Washington, 2009.

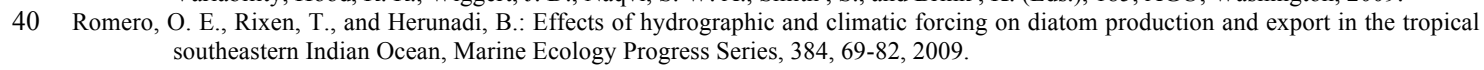

Ryther, J. H. and Menzel, D. W.: On the production composition and distribution of organic matter in the Western Arabian Sea, Deep Sea Research, 12, 199-209, 1965.

Sarmiento, J. L., Gruber, N., Brzezinski, M. A., and Dunne, J. P.: High-latitude controls of thermocline nutrients and low latitude biological productivity, Nature, 427, 56-60, 2004.

Sarmiento, J. L. and Toggweiler, J. R.: A new model for the role of the oceans in determining atmospheric pCO 2 , Nature, 308, 621-624, 1984.

Sastry, J. S. and D'Souza, R. S.: Upwelling \& Upward Mixing in the Arabian Sea, Indian Journal of Marine Sciences, 1, $17-27,1972$.

Schiebel, R., Barker, S., Lendt, R., Thomas, H., and Bollmann, J.: Planktic foraminiferal dissolution in the twilight zone, Deep Sea Research Part II: Topical Studies in Oceanography, 54, 676-686, 2007.

Schiebel, R. and Hemleben, C.: Interannual variability of planktic foraminiferal populations and test flux in the eastern North Atlantic Ocean (JGOFS), Deep Sea Research Part II: Topical Studies in Oceanography, 47, 1809-1852, 2000.

Schneider, U., Becker, A., Finger, P., Meyer-Christoffer, A., Rudolf, B., and Ziese, M.: http://dx.doi.org/10.5676/DWD GPCC/MP M V4 1002014.

55 Schott, F. and McCreary, J. P., Jr.: The monsoon circulation of the Indian Ocean, Progress in Oceanography, 51, 1 - 123, 2001.

Siegenthaler, U. and Wenk, T.: Rapid atmospheric $\mathrm{CO}_{2}$ variations and ocean circulation, Nature, 308, 624-627, 1984. 
Biogeosciences Discuss., https://doi.org/10.5194/bg-2017-317

Manuscript under review for journal Biogeosciences

Discussion started: 25 August 2017

(C) Author(s) 2017. CC BY 4.0 License.

Smayda, T. J.: Normal and Accelerated Sinking of Phytoplankton in the Sea, Marine Geology, 11, 105-122, 1971.

Smayda, T. J.: The suspension and sinking of phytoplankton in the sea, Oceanography Marine Biology Annual Review, 8, $353-414$, 1970 .

Smith, T. M., Reynolds, R. W., Peterson, T. C., and Lawrimore, J.: Improvements to NOAA's historival merged land-ocean surface temperature analysis (1880 - 2006), Journal of Climate, 21, 2283 - 2296, 2008.

Stokes, D. and Reynolds, R. W., 2010.

Stommel, H.: Determination of water mass properties of water pumped down from the Ekman layer to the geostrophic flow below, Proceedings of the National Academy of Sciences, 76, 3051-3055, 1979.

Suess, E.: Particulate organic carbon flux in the oceans - surface productivity and oxygen utilization, Nature, 288, 260-263, 1980

10 Susanto, R. D., Gordon, A. L., and Zengh, Q.: Upwelling along the coasts of Java and Sumatra and its relation to ENSO, Journal of Marine Research Letters, 28, 1599-1602, 2001.

Suzuki, N. and Kato, K.: Studies on suspended materials.Marine snow in the sea, part 1. Source of marine snow. , Hokkaido University 4 , 132-135., Bulletin of the Faculty of Fisheries, Hokkaido University, 4, 132 -135, 1953.

Syvitski, J. P. M., Vörösmarty, C. J., A.J., K., and Green, P.: Impact of humans on the flux of terrestrial sediment to the global ocean, Science, 308, 376 - 380, 2005.

Turner, J. T.: Zooplankton fecal pellets, marine snow and sinking phytoplankton blooms Aquatic Microbial Ecology, 27, 57-102, 2002.

Unger, D., Ittekkot, V., Schafer, P., Tiemann, J., and Reschke, S.: Seasonality and interannual variability of particle fluxes to the deep Bay of Bengal: influence of riverine input and oceanographic processes, Deep Sea Research Part II: Topical Studies in Oceanography, 50, 897-923, 2003.

20 Volk, T. and Hoffert, M. I.: The carbon cycle and atmospheric $\mathrm{CO}_{2}$, natural variation archean to present. In: The Carbon Cycle and Atmospheric $\mathrm{CO}_{2}$ : Natural Variations Archean to Present, Sundquist, E. T. and Broecker, W. S. (Eds.), AGU, Washington, 1985.

Wagner, W. and Pruß, A.: The IAPWS Formulation 1995 for the Thermodynamic Properties of Ordinary Water Substance for General and Scientific Use, Journal of Physical and Chemical Reference Data, 31, 387-535, 2002.

Wang, P.: Global monsoon in a geological perspective, Chinese Science Bulletin, 54, 1113-1136, 2009.

25 Wang, P., Clemens, S., Beaufort, L., Braconnot, P., Ganssen, G., Jian, Z., Kershaw, P., and Sarnthein, M.: Evolution and variability of the Asian monsoon system: state of the art and outstanding issues, Quaternary Science Reviews, 24, 595-629, 2005.

Wanninkhof, R.: Relationship between gas exchange and wind speed over the ocean, Journal of Geophysical Research, 97, 7373-7381, 1992.

Westberry, T. K., Williams, P. J. 1. B., and Behrenfeld, M. J.: Global net community production and the putative net heterotrophy of the oligotrophic oceans, Global Biogeochemical Cycles, 26, GB4019, 2012.

Wilson, J. D., Barker, S., and Ridgwell, A. Assessment of the spatial variability in particulate organic matter and mineral sinking fluxes in the ocean interior: Implications for the ballast hypothesis, Global Biogeochemical Cycles, 26, GB4011, 2012.

Winter, A. and Siesser, W. G.: Coccolithophores, Cambridge University Press, New York, 1994.

Zeebe, R. E. and Wolf-Gladrow, D.: $\mathrm{CO}_{2}$ In Seawater: Equilibrium, Kinetics, Isotopes, Elsevier Science B. V., Amsterdam,The Netherlands, 2001.

\section{Captions}

Figure 1: Particulate organic carbon flux (POC) versus water-depth. The red line indicates the organic carbon fluxes

40 calculated based on the equation obtained from Rixen et al. (2002). A primary production of about $205 \mathrm{~g} \mathrm{~m}^{-2} \mathrm{year}^{-1}$ representing the mean primary production in the Arabian Sea (Rixen et al., 2002) was used for calculating the POC flux. The equation introduced by Eppley and Peterson (1979) was used to convert primary into export production $\left(105 \mathrm{~g} \mathrm{~m}^{-2}\right.$ year $^{-1}$; Export $=0.0025 *$ (primary productions) ${ }^{2}$ ) which in addition to mean organic carbon and total flux measures at out trap sites (Tab. 1) were used to compute the flux of free and protected organic carbon based on the 45 equations given by Armstrong et al. (2002). The blue line shows the Martin curve (Martin et al., 1987) for which an export production of about $50 \mathrm{~g} \mathrm{~m}^{-2}$ year $^{-1}$ was use to meet the sediment trap data indicated by black circle.

Figure 1: Particulate organic carbon flux (POC) versus water-depth. The red line indicates the organic carbon fluxes calculated

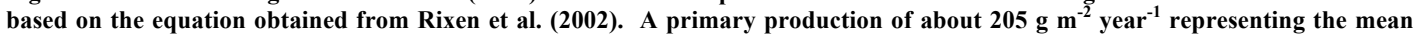
primary production in the Arabian Sea (Rixen et al., 2002) was used for calculating the POC flux. The equation introduced by 50 Eppley and Peterson (1979) was used to convert primary into export production $\left(105 \mathrm{~g} \mathrm{~m}^{-2}\right.$ year $^{-1} ; \mathbf{E x p o r t}^{-0.0025}{ }^{*}\left(\mathrm{primary}^{2}\right.$ 
Biogeosciences Discuss., https://doi.org/10.5194/bg-2017-317

Manuscript under review for journal Biogeosciences

Discussion started: 25 August 2017

(C) Author(s) 2017. CC BY 4.0 License.

\section{(c) (i)}

productions) ${ }^{2}$ ) which in addition to mean organic carbon and total flux measures at out trap sites (Tab. 1) were used to compute the flux of free and protected organic carbon based on the equations given by Armstrong et al. (2002). The blue line shows the Martin curve (Martin et al., 1987) for which an export production of about $50 \mathrm{~g} \mathrm{~m}^{-2}$ year $^{-1}$ was use to meet the sediment trap data indicated by black circle.

5 Figure 2: Bathymetric chart of the northern Indian Ocean and the adjacent land mass. Data were obtained from http://Ingrid.Idgo. Columbia.edu/SOURCE/WORLDBATH. White circles show the sediment trap sites operated by the joint Indo/German and Indonesian German projects (see Tab. 2-1). The black circles and diamonds represent the U.S. JGOFS sediment trap site M1 to M5 (Honjo et al., 1999; Lee et al., 1998) and the Dutch sediment trap sites in the Arabian Sea and off Somalia (Koning et al., 1997).

10 Figure 3: Monthly mean precipitation rates during the boreal winter (January) and summer (July). The data over the ocean were obtained form the Hamburg Ocean Atmosphere Parameters and Fluxes from Satellite Data (Andersson et al., 2010) and those over land from the Global Precipitation Climatology Centre, Landsurface Monitoring Product 1.0 (Schneider et al., 2011). The averaged data cover the period between 1987 and 1998 . The black line indicates the area influenced by the monsoon.

Figure 4: Monthly mean sea surface temperature in the Indian Ocean (Smith et al., 2008) and the surface ocean circulation 15 simplified and redrawn for Schott and McCreary (2001). The arrows indicate the South Equatorial Current (SEC), South Monsoon Current (SMC), Sri Lanka Dome (SD), East Indian Coastal Current (EICC), South Java Current (SJC), Indonesian Through Flow (ITF), Somali Current (SC), Great Whirl (GW), Ras al Had Jet (RHJ), West Indian Coastal Current (WICC), North Monsoon Current (NMC). The black circles show the sediment trap sites (Fig. 2, Tab. 1).

Figure 5: (a) Monthly mean organic carbon fluxes (POC) obtained from our sediment trap experiments at stations where 20 monsoon-driven upwelling and vertical mixing cause a pronounced seasonally and (b) at sites where seasonality is weak. The POC fluxes were normalized to a water-depth of $2000 \mathrm{~m}$ by using the equation introduced by Rixen et al. (2002).

Figure 6: Organic carbon fluxes (bars), sea surface temperatures (Stokes and Reynolds, 2010) selected for the sampling site JAM. The precipitation rates (Schneider et al., 2011) were averaged for entire Indonesia. Grey bars indicate the rainy and the upwelling season.

25 Figure 7: Monthly mean primary production rates (Behrenfeld and Falkowski, 1997b) selected for the sediment trap location. The data were downloaded from the web site 'ocean productivity' ( $O$ 'Malley, 2015) and covered the periods between 2002 and 2014.

Figure 8: Organics carbon fluxes measure at JAM and the primary production rates selected for the JAM site. The primary production rates were downloaded from the web site 'ocean productivity' ( $O$ 'Malley, 2015).

Figure 9: (a) Monthly mean primary production rates (Behrenfeld and Falkowski, 1997b) our trap sites WAST and JAM. (b)

30 Monthly mean organic carbon fluxes (POC) obtained from the sediment trap sites WAST and JAM as well as the monthly mean precipitation rates over Indonesia obtained from the DWD (2010).

Figure 10: (a) The proportion of the exported organic carbon, which reaches the water-depth of $2000 \mathrm{~m}$ and the respective respiration of the organic matter in the water column during the summer, winter and intermonsoon seasons at our trap sites. These two fractions add to $100 \%$. This means that if e.g. $2 \%$ of the export production reaches the water-depth of $2000 \mathrm{~m} 98 \%$ of

35 the export organic matter is respired. Black and red circles indicate data from the Arabian Sea stations WAST, CAST, and EAST, which were used to fit the curves. Magenta and grey circles show the other data. (b) Excess organic carbon fluxes (POC Excess) versus the lithogenic matter content.

Figure 11: (a) The proportion of the exported organic carbon, which reaches the water-depth of $2000 \mathrm{~m}$ and the respective respiration of the organic matter in the water column versus the export production. Contrary to figure 10a the annual mean rates

40 were used to calculate the presented data. Magenta and the grey circles indicate the data from the Indian Ocean and the red and black circles show sediment trap data obtained from a global compilation (Wilson et al., 2012). (b) Annual men carbonate carbon (particulate inorganic carbon, PIC) versus annual mean organic carbon fluxes and (c) the annual mean PIC flux versus the export production. As in (a) the export production was derived from primary production rates according the equation obtained form Eppley and Peterson (1979). Red and grey circles reveal data from the Indian Ocean and sediment trap data obtained from a 45 global compilation, respectively. 
Biogeosciences Discuss., https://doi.org/10.5194/bg-2017-317

Manuscript under review for journal Biogeosciences

Discussion started: 25 August 2017

(C) Author(s) 2017. CC BY 4.0 License.

\section{(c) (i)}

Figure 12: Densities of bulk components (red lines) as compiled from literature. Black circles and lines indicate the densities of crystalline analogues whereas the black circle with the row 'Clay' indicate the density of illite. The grey area shows the density range of sea water.

Figure 13: Lithogenic matter content versus the density of the solid (a), the annual mean organic carbon fluxes determined at our 5 sediment trap (b) as well as organic carbon fluxes measure at our sites in the Indian Ocean (red circles) and at other sites world wide (black circles). The global data set was obtained from Wilson et al. (2002). The black line in (b) indicates the results from experiment 2 (Tab. 3) and the blue line shows the results form experiment 4 (Tab. 3.)

Figure 14: The organic carbon fluxes (POC) versus the density of the solids (a) and carbonate carbon (particulate inorganic carbon, PIC) flux (b). The red circle indicate trap sites influenced by upwelling in the Arabian Sea and the southern Bay of

10 Bengal (SBBT), the blue circle show the data from the rive-dominated regions in the Bay of Bengal and off South Java and the grey circles show the sediment trap data from the U.S. JGOFS site in the Arabian Sea (Honjo et al., 1999). The arrows indicate the main forcing mechanism.

Figure 15: The particulate organic carbon (POC, black line), oxygen concentrations (blue line), change of oxygen with depth (= oxygen consumption, red line), and nitrite concentrations versus water-depth. The deeper secondary nitrite maximum indicates

15 active denitrification. Figure (a) shows the upper $500 \mathrm{~m}$ and figure (b) the upper $3500 \mathrm{~m}$ of the water column. The data were measured during the German RV Meteor cruise M74 in 2007 at our station CAST (RV Meteor station 950). For further information see Rixen et al. (2014) and Gaye et al. (2013). An export production of $105 \mathrm{~g} \mathrm{~m}^{-2}$ year $^{-1}$ (see Tab. 3) and equation (2) was used to calculate the POC flux. Furthermore it was assumed that approximately $11 \%$ of the organic matter $\left(11.6 \mathrm{~g} \mathrm{~m}^{-2}\right.$ year $^{-1}$, Tab. 3 -Exp. 3) was exported in fast sinking particles $\left(214 \mathrm{~m} \mathrm{day}^{-1}\right)$ and $89 \%$ in slow sinking particle $\left(8 \mathrm{~m} \mathrm{day}^{-1}\right)$. The oxygen 20 consumption and the deep nitrite maximum suggest that the slow sinking particles were respired by oxic-respiration and denitrification in the upper and lower part of the seasonal thermocline. The shaded area indicates the respiration of slow sinking particles. The black circle in (b) shows the mean organic carbon flux of $2.74 \mathrm{~g} \mathrm{~m}^{-2}$ year-1 as measured by our sediment traps (Tab. 2).

Figure 16: Schematic of the nutrient cycle in the open ocean.

Figure 17: Schematic of the model structure including the results of Experiments 1 (see Tab. 4).

Table 1: Number of station, trap ID, station name, position, water-depth, and trap depth.

Table 2: Trap ID, annual mean bulk fluxes and contents, as well as the density of the solids (Den) and contribution of lithogenic matter to the density of the solids (L-Den.). The EPT trap was deployed at a water-depth of only $590 \mathrm{~m}$ (see Tab. 1) and therewith 30 within a depth-range at which trap results are assumed to be heavily biased by physical and biological processes (Honjo et al. 2008). The time-series obtained at the tap site NAST and WPT covered no full annual cycle and were therefore also excluded.

Table 3:Parameters chosen to calculate the impact of the density of the solids on the export production by combining equations 2 , $4,5,9$, and 10 . The equation to calculate the density of the sold from the lithogenic matter content measured in the trap samples are obtained from figure 13a.

35 Table 4: Results obtained from the numerical model experiments (see Fig.:17). Total alkalinity (TA) and concentrations of total dissolved inorganic carbon (DIC), the $\mathrm{CO}_{2}$ concentration in the atmosphere, the export production (Exp.) and the organic carbon flux out of the seasonal thermocline (POC), the fraction of the exported organ matter which was exported out the seasonal thermocline (frac.) and the ratio between the organic carbon and carbonate carbon export (rain). WAO indicate that the data were selected from World Ocean Atlas (Garcia et al., 2010) and from Goyet et al. (2000) and averaged globally for the respective water-depth (euphotic zone $0-100 \mathrm{~m}$, seasonal thermocline $(100-300 \mathrm{~m})$, and the deep sea $(>350 \mathrm{~m})$ ). 
Biogeosciences Discuss., https://doi.org/10.5194/bg-2017-317

Manuscript under review for journal Biogeosciences

Discussion started: 25 August 2017

(c) Author(s) 2017. CC BY 4.0 License.

(c) (i)

Table 1. Number of station, trap ID, station name, position, water-depth, and trap depth.

\begin{tabular}{|r|l|l|r|r|r|c|}
\hline No. & Trap ID & Name & Lat. & Lon. & $\begin{array}{l}\text { W- } \\
\text { Depth }\end{array}$ & T-Depth \\
\hline & & & {$\left[{ }^{\circ} \mathrm{N}\right]$} & {$\left[{ }^{\circ} \mathrm{N}\right]$} & {$[\mathrm{m}]$} & {$[\mathrm{m}]$} \\
\hline 1 & WAST & Western Arabian Sea Trap Station & 16.26 & 60.58 & 4032 & 3017 \\
\hline 2 & CAST & Central Arabian Sea Trap Station & 14.51 & 64.72 & 3920 & 2944 \\
\hline 3 & EAST & Eastern Arabian Sea Trap Station & 15.57 & 68.73 & 3791 & 2870 \\
\hline 4 & NAST & Northern Arabian Sea Trap Station & 19.98 & 65.73 & 3147 & 2478 \\
\hline 5 & EPT & East Pakistan Trap Station & 24.77 & 65.82 & 1093 & 590 \\
\hline 6 & WPT & West Pakistan Trap Station & 24.60 & 65.59 & 1900 & 1466 \\
\hline 7 & NEAST & Northeastern Arabian Sea Trap Station & 16.93 & 67.84 & 3545 & 3039 \\
\hline 8 & SAST & Southern Arabian Sea Trap Station & 11.60 & 66.08 & 4243 & 3032 \\
\hline 9 & EIOT & Equatorial Indian Ocean Trap Station & 3.56 & 77.78 & 3400 & 2374 \\
\hline 10 & NBBT-N & Northern Bay of Bengal Trap Station - North & 17.42 & 89.65 & 2267 & 1889 \\
\hline 11 & NBBT-S & Northern Bay of Bengal Trap Station - South & 15.48 & 89.45 & 2709 & 2172 \\
\hline 12 & CBBT-N & Central Bay of Bengal Trap Station - North & 13.14 & 84.41 & 3266 & 2261 \\
\hline 13 & CBBT-S & Central Bay of Bengal Trap Station - South & 11.03 & 84.43 & 3462 & 2527 \\
\hline 14 & SBBT & Southern Bay of Bengal Trap Station & 5.09 & 87.26 & 3995 & 2976 \\
\hline 15 & JAM & Java Mooring & -8.28 & 108.02 & 3250 & 2456 \\
\hline
\end{tabular}


Biogeosciences Discuss., https://doi.org/10.5194/bg-2017-317

Manuscript under review for journal Biogeosciences

Discussion started: 25 August 2017

(C) Author(s) 2017. CC BY 4.0 License.

Table 2. Trap ID, annual mean bulk fluxes and contents, as well as the density of the solids (Den) and contribution of lithogenic matter to the density of the solids (L-Den.). The EPT trap was deployed at a water-depth of only $590 \mathrm{~m}$ (see Tab. 3-1) and therewith within a depth-range at which trap results are assumed to be heavily biased by physical and biological processes (Honjo et al. 2008). The time-series obtained at the tap site NAST and WPT covered no full annual cycle and were therefore also 5 excluded.

\begin{tabular}{|c|c|c|c|c|c|c|c|c|c|c|c|}
\hline Trap ID & $\begin{array}{l}\text { Total } \\
\text { Total }\end{array}$ & POC & $\mathrm{CaCO}_{3}$ & Opal & Lith. & POC & $\mathrm{CaCO}_{3}$ & Opal & Lith. & \multirow{2}{*}{$\frac{\text { Den. }}{\left[\mathrm{g} \mathrm{cm}^{-3}\right]}$} & \multirow{2}{*}{$\begin{array}{c}\text { L-Den. } \\
{[\%]}\end{array}$} \\
\hline & \multicolumn{5}{|c|}{$\left[\mathrm{g} \mathrm{m}^{-2}\right.$ year $\left.^{-1}\right]$} & \multicolumn{4}{|c|}{$[\%]$} & & \\
\hline WAST & 55.87 & 3.13 & 29.16 & 13.08 & 8.01 & 5.60 & 52.18 & 23.40 & 14.34 & 1.74 & 21.65 \\
\hline CAST & 36.85 & 2.29 & 22.08 & 4.88 & 5.78 & 6.20 & 59.91 & 13.25 & 15.68 & 1.73 & 23.71 \\
\hline EAST & 34.40 & 2.09 & 17.94 & 5.43 & 7.27 & 6.07 & 52.16 & 15.78 & 21.14 & 1.79 & 30.93 \\
\hline EPT & 443.82 & 11.93 & 62.67 & 33.44 & 326.23 & 2.69 & 14.12 & 7.53 & 73.50 & 2.34 & 82.40 \\
\hline NEAST & 64.69 & 4.45 & 29.44 & 8.52 & 18.72 & 6.87 & 45.51 & 13.17 & 28.94 & 1.86 & 40.82 \\
\hline SAST & 43.68 & 2.27 & 27.10 & 5.95 & 6.53 & 5.21 & 62.05 & 13.63 & 14.95 & 1.74 & 22.57 \\
\hline EIOT & 27.86 & 1.52 & 16.36 & 5.21 & 3.57 & 5.44 & 58.72 & 18.69 & 12.80 & 1.72 & 19.52 \\
\hline NBBT-N & 47.75 & 2.89 & 13.30 & 10.39 & 18.85 & 6.06 & 27.85 & 21.76 & 39.48 & 1.98 & 52.25 \\
\hline NBBT-S & 33.71 & 2.21 & 10.96 & 7.70 & 11.08 & 6.55 & 32.50 & 22.85 & 32.86 & 1.91 & 45.08 \\
\hline CBBT-N & 54.41 & 2.90 & 15.50 & 11.74 & 21.94 & 5.34 & 28.49 & 21.57 & 40.33 & 2.00 & 52.96 \\
\hline CBBT-S & 34.84 & 1.99 & 13.38 & 8.92 & 8.95 & 5.72 & 38.41 & 25.60 & 25.70 & 1.85 & 36.40 \\
\hline SBBT & 39.93 & 2.25 & 19.96 & 9.81 & 6.11 & 5.64 & 49.99 & 24.56 & 15.30 & 1.75 & 22.96 \\
\hline JAM & 141.70 & 4.84 & 15.10 & 31.27 & 86.61 & 3.42 & 10.66 & 22.07 & 61.12 & 2.22 & 72.07 \\
\hline Mean & 51.31 & 2.74 & 19.19 & 10.24 & 16.95 & 5.68 & 43.20 & 19.69 & 26.89 & 1.86 & 36.74 \\
\hline Std. & 29.16 & 0.96 & 6.14 & 6.83 & 21.77 & 0.83 & 15.10 & 4.41 & 13.98 & 0.14 & 15.70 \\
\hline
\end{tabular}


Biogeosciences Discuss., https://doi.org/10.5194/bg-2017-317

Manuscript under review for journal Biogeosciences

Discussion started: 25 August 2017

Table 3. Parameters chosen to calculate the impact of the density of the solids on the export production by combining equations 2 , $4,5,9$, and 10. The equation to calculate the density of the sold from the lithogenic matter content measured in the trap samples are obtained from figure 3-13a.

\begin{tabular}{|l|r|r|r|r|r|}
\hline Parameters & \multicolumn{1}{|c|}{ Exp. 1 } & Exp. 2 & Exp. 3 & \multicolumn{1}{c|}{ Exp. 4 } & \multicolumn{1}{c|}{ Units } \\
\hline Primary production & 205.00 & & & & $\mathrm{~g} \mathrm{~m}^{-2}$ year $^{-1}$ \\
\hline Export production (POC euphotic) & 105.00 & & 11.60 & & $\mathrm{~g} \mathrm{~m}^{-2}$ year $^{-1}$ \\
\hline Organic carbon flux (POC(z)) & 2.74 & $0.7-9.2$ & 2.74 & $1.7-4.5$ & $\mathrm{~g} \mathrm{~m}^{-2}$ year $^{-1}$ \\
\hline Decay constant $(\lambda)$ & 0.106 & 0.106 & 0.106 & 0.106 & day $^{-1}$ \\
\hline Water-depth (z) & 3000 & 3000 & 3000 & 3000 & $\mathrm{~m}$ \\
\hline Depth of the euphotic zone & 105 & 105 & 105 & 105 & $\mathrm{~m}$ \\
\hline Sinking speed & 84.5 & 84.5 & 214 & 214 & $\mathrm{~m} \mathrm{day}^{-1}$ \\
\hline Particle radius & 0.1 & 0.1 & 0.1 & 0.1 & $\mathrm{~cm}$ \\
\hline Temperature & 10 & 10 & 10 & 10 & ${ }^{\circ} \mathrm{C}$ \\
\hline Salinity & 35 & 35 & 35 & 35 & $\mathrm{~g} \mathrm{~cm}^{-3}$ \\
\hline Sea water density (S,T) & 1.0270 & 1.0270 & 1.0270 & 1.0270 & $\mathrm{~g} \mathrm{~cm}^{-1} \mathrm{~s}^{-1}$ \\
\hline Viscosity (S,T) & 0.0127 & 0.0127 & 0.0127 & 0.0127 & \\
\hline Porosity & 0.9993 & 0.9993 & 0.9993 & 0.9993 & $\mathrm{~g} \mathrm{~cm}^{-3}$ \\
\hline Density of the solids & 1.9 & $0.0112 *$ & 1.9 & $0.0112 *$ & Lith(\%)+ \\
& & Lith(\%)+ & & 1.58 & \\
\hline
\end{tabular}


Biogeosciences Discuss., https://doi.org/10.5194/bg-2017-317

Manuscript under review for journal Biogeosciences

Discussion started: 25 August 2017

Table 4. Results obtained from the numerical model experiments (see Fig. 3-17). Total alkalinity (TA) and concentrations of total dissolved inorganic carbon (DIC), the $\mathrm{CO}_{2}$ concentration in the atmosphere, the export production (Exp.) and the organic carbon flux out of the seasonal thermocline (POC), the fraction of the exported organ matter which was exported out the seasonal thermocline (frac.) and the ratio between the organic carbon and carbonate carbon export (rain). WAO indicate

5 that the data were selected from World Ocean Atlas (Garcia et al., 2010) and from Goyet et al. (2000) and averaged globally for the respective water-depth (euphotic zone $0-100 \mathrm{~m}$, seasonal thermocline $(100-300 \mathrm{~m})$, and the deep sea $(>350 \mathrm{~m})$ ).

\begin{tabular}{|c|c|c|c|c|c|c|c|c|c|c|c|}
\hline & $\begin{array}{l}\text { TA } \\
\text { wOA }\end{array}$ & TA & $\begin{array}{l}\mathrm{PO}_{4 .} \\
\text { WOA }\end{array}$ & $\mathrm{PO}_{4}$ & $\begin{array}{l}\text { DIC } \\
\text { wOA }\end{array}$ & DIC & $\begin{array}{l}\mathrm{CO}_{2} \\
\text { Atm. }\end{array}$ & Exp. & POC & frac. & rain \\
\hline & \multicolumn{2}{|c|}{$\mu$ eq. } & \multicolumn{4}{|c|}{$\mu \mathrm{M}$} & ppm & \multicolumn{2}{|c|}{$\mathrm{PgC}$ year ${ }^{-1}$} & & \\
\hline Experiment 1 & & & & & & & 280 & 10.67 & 1.07 & 0.1 & 0.70 \\
\hline Euphotic zone & 2307 & 2377 & 0.77 & 1.27 & 2053 & 1934 & & & & & \\
\hline S. thermocline & 2313 & 2378 & 1.26 & 1.28 & 2133 & 1936 & & & & & \\
\hline Deep sea & 2343 & 2499 & 2.19 & 2.19 & 2248 & 2100 & & & & & \\
\hline Experiment 2 & & & & & & & 245 & 7.65 & 1.53 & 0.2 & 0.70 \\
\hline Euphotic zone & & 2330 & & 0.91 & & 1873 & & & & & \\
\hline S. thermocline & & 2331 & & 0.92 & & 1874 & & & & & \\
\hline Deep sea & & 2505 & & 2.23 & & 2110 & & & & & \\
\hline Experiment 3 & & & & & & & 280 & 7.65 & 1.53 & 0.2 & 1.12 \\
\hline Euphotic zone & & 2224 & & 0.91 & & 1817 & & & & & \\
\hline S. thermocline & & 2225 & & 0.92 & & 1818 & & & & & \\
\hline Deep sea & & 2516 & & 2.23 & & 2112 & & & & & \\
\hline Experiment 4 & & & & & & & 174 & 26.84 & 2.68 & 0.1 & 0.70 \\
\hline Euphotic zone & & 2210 & & 0.00 & & 1718 & & & & & \\
\hline S. thermocline & & 2212 & & 0.02 & & 1722 & & & & & \\
\hline Deep sea & & 2517 & & 2.32 & & 2135 & & & & & \\
\hline & & & & & & & & & & & \\
\hline Experiment 5 & & & & & & & & & & & \\
\hline Euphotic zone & & 2210 & & 0.00 & & 1718 & 174 & 13.48 & 2.70 & 0.2 & 0.70 \\
\hline S. thermocline & & 2211 & & 0.01 & & 1720 & & & & & \\
\hline Deep sea & & 2517 & & 2.32 & & 2136 & & & & & \\
\hline
\end{tabular}


Biogeosciences Discuss., https://doi.org/10.5194/bg-2017-317

Manuscript under review for journal Biogeosciences

Discussion started: 25 August 2017

(C) Author(s) 2017. CC BY 4.0 License.

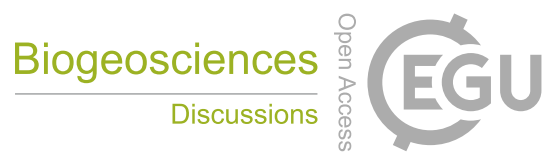

(c)

Figure 1

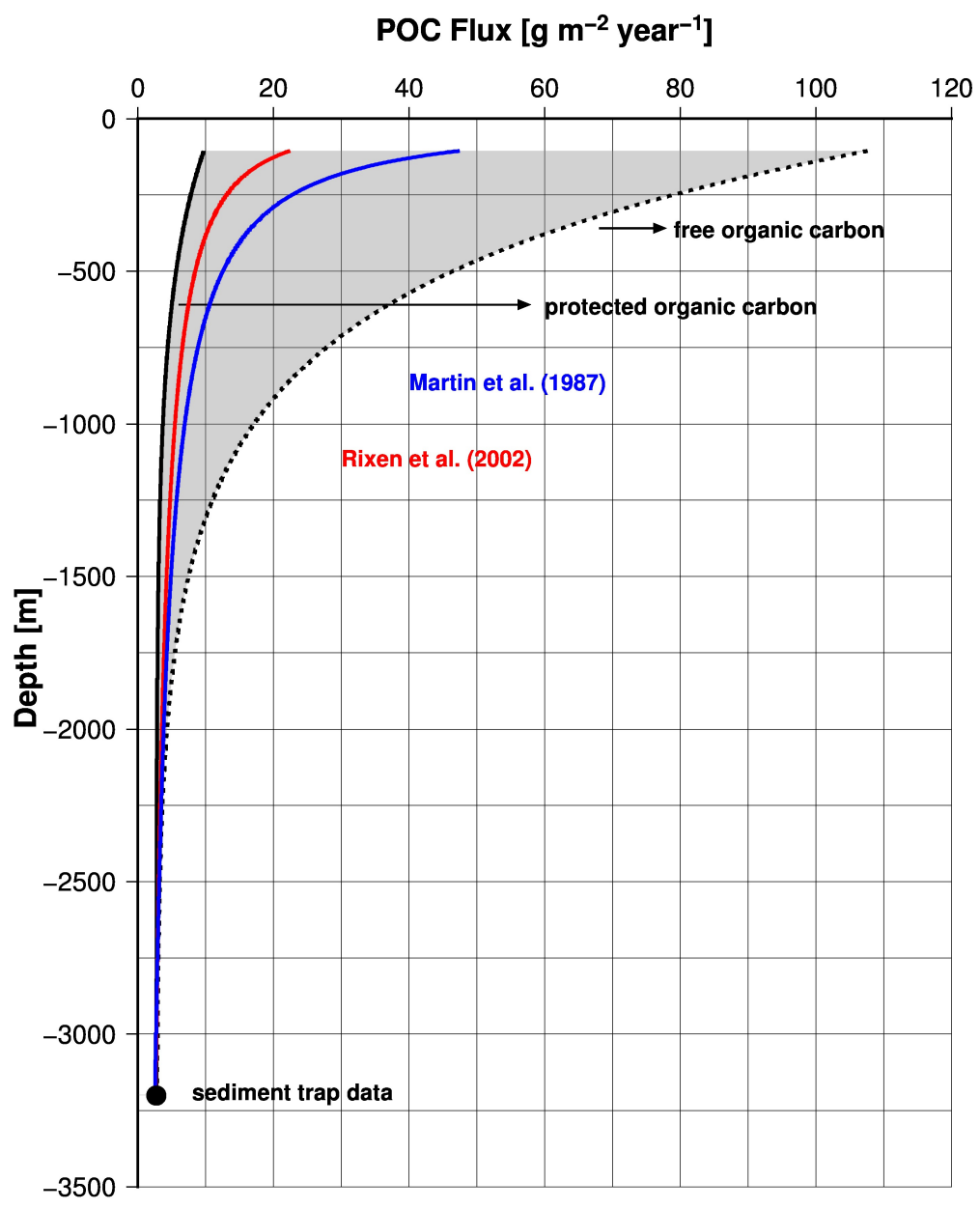


Biogeosciences Discuss., https://doi.org/10.5194/bg-2017-317

Manuscript under review for journal Biogeosciences

Discussion started: 25 August 2017

(c) Author(s) 2017. CC BY 4.0 License.

Figure 2

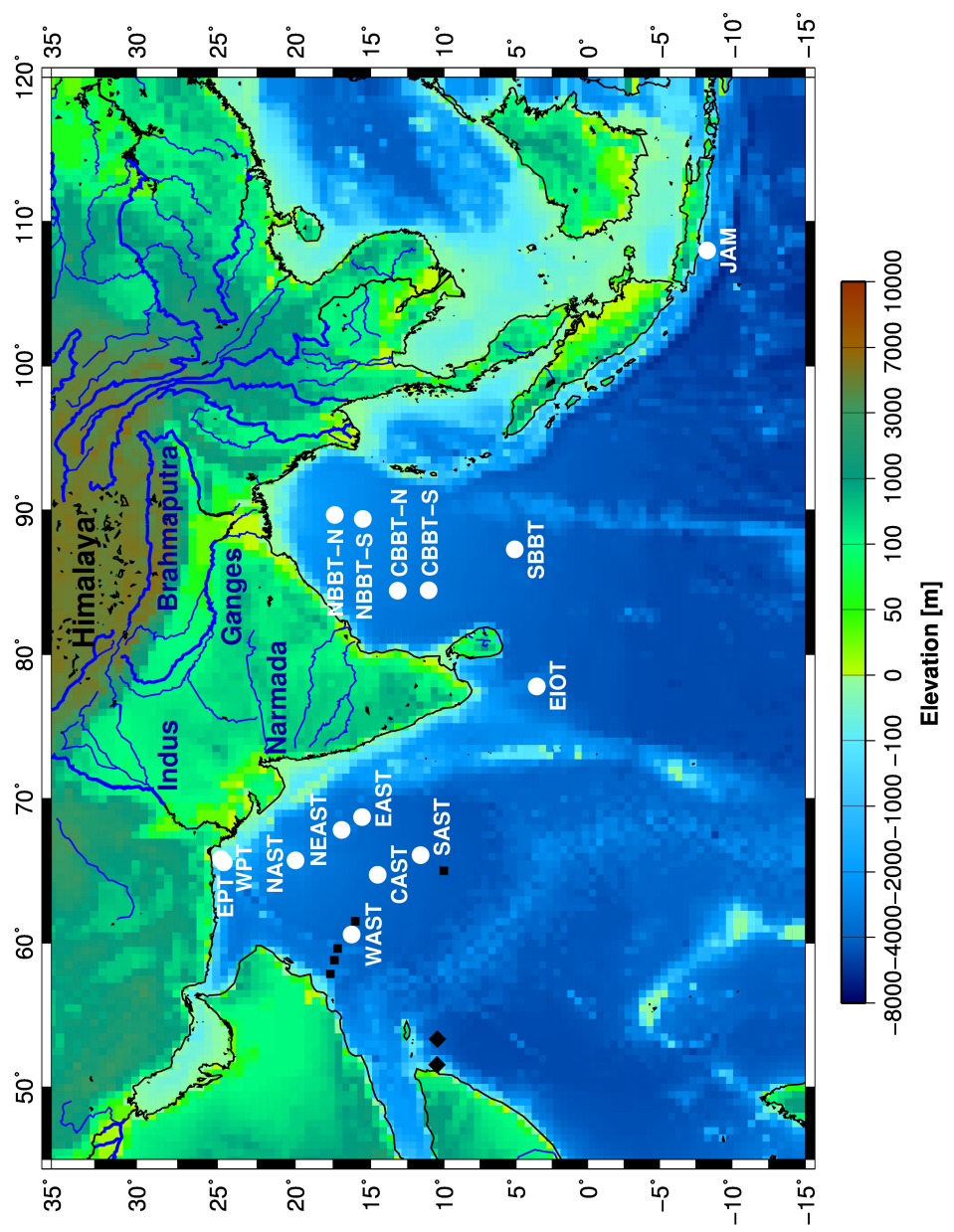


Biogeosciences Discuss., https://doi.org/10.5194/bg-2017-317

Manuscript under review for journal Biogeosciences

Discussion started: 25 August 2017

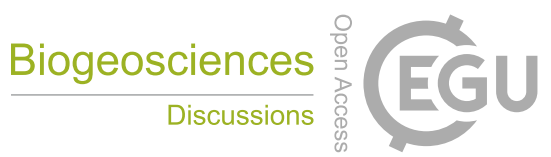

(c) Author(s) 2017. CC BY 4.0 License.

(c) $\underset{\mathrm{Br}}{(\mathrm{i})}$

Figure 3
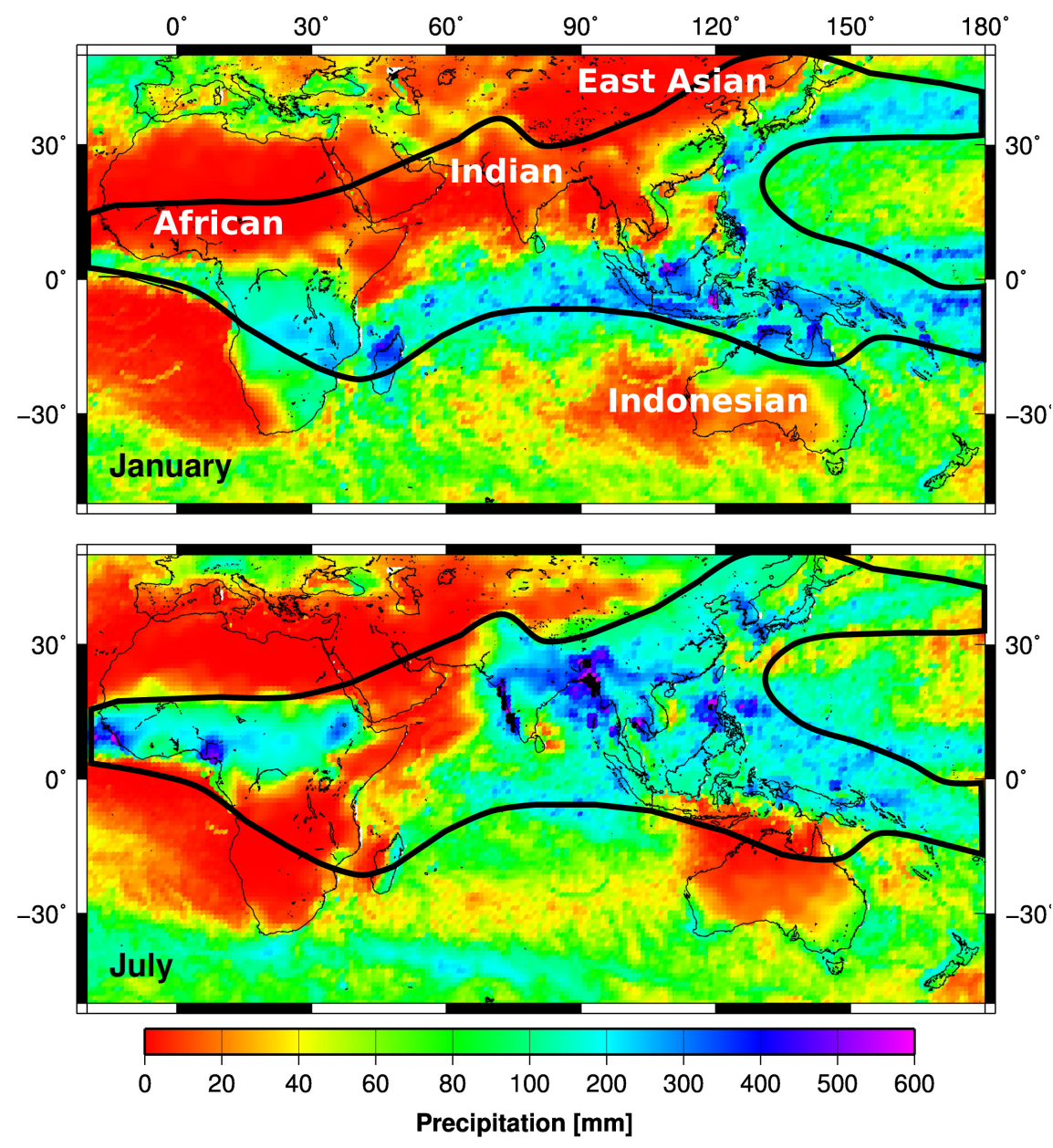
Biogeosciences Discuss., https://doi.org/10.5194/bg-2017-317

Manuscript under review for journal Biogeosciences

Discussion started: 25 August 2017

(c) Author(s) 2017. CC BY 4.0 License.

(c) (1)

Figure 4
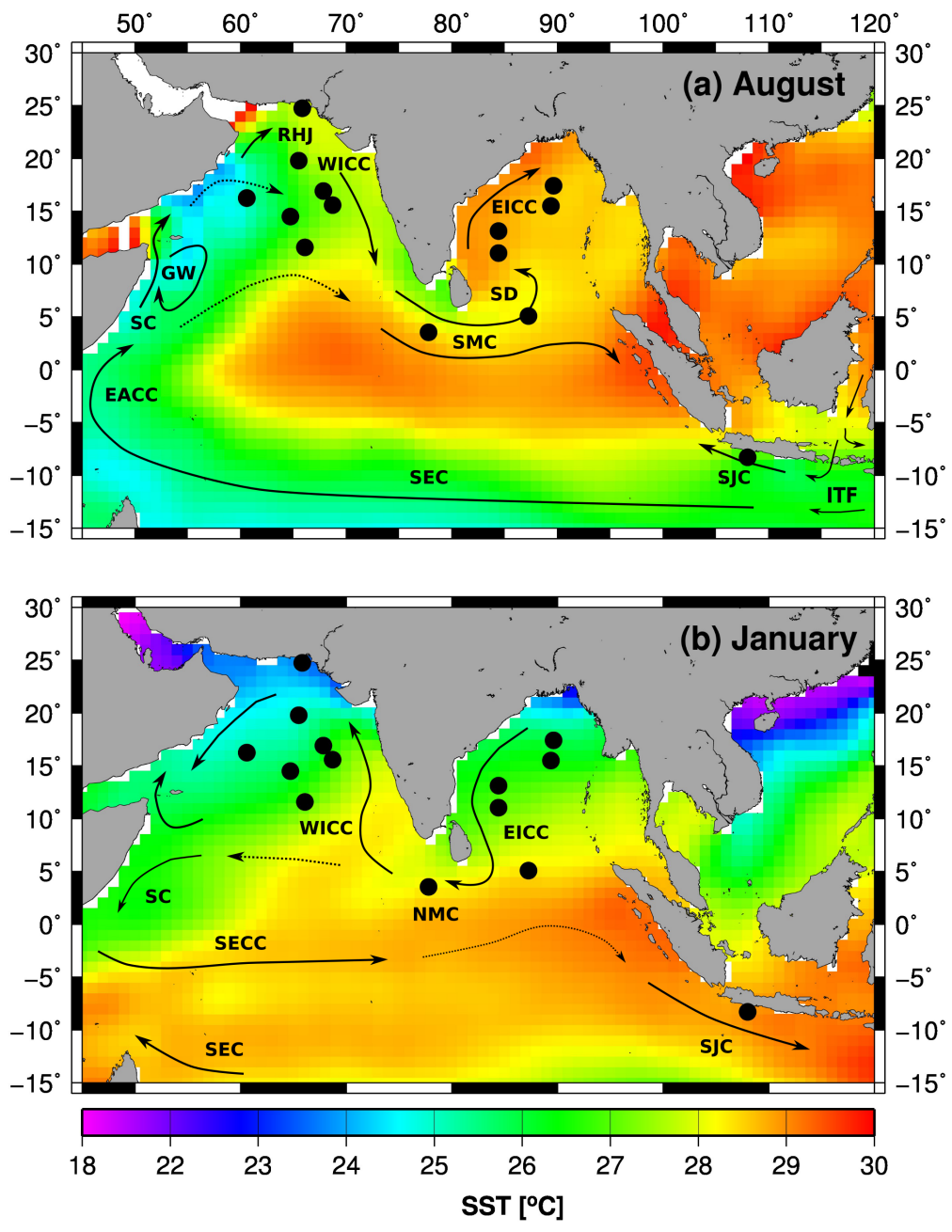
Biogeosciences Discuss., https://doi.org/10.5194/bg-2017-317

Manuscript under review for journal Biogeosciences

Discussion started: 25 August 2017

(c) Author(s) 2017. CC BY 4.0 License.

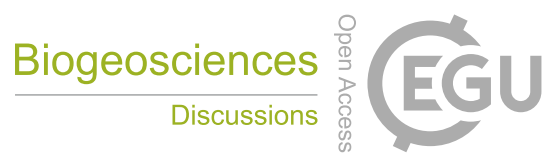
(c) (i)

Figure 5

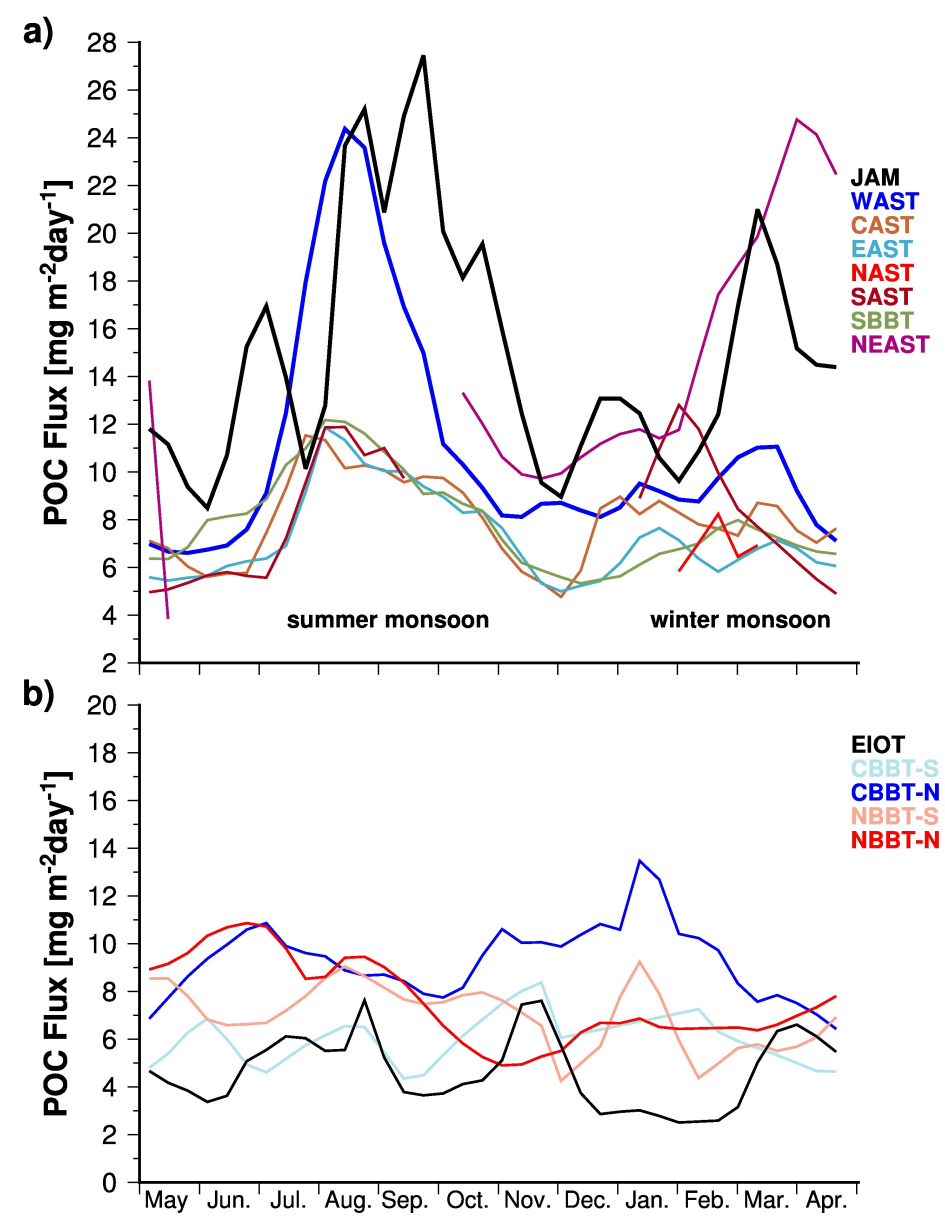


Biogeosciences Discuss., https://doi.org/10.5194/bg-2017-317

Manuscript under review for journal Biogeosciences

Discussion started: 25 August 2017

(c) Author(s) 2017. CC BY 4.0 License.

Figure 6

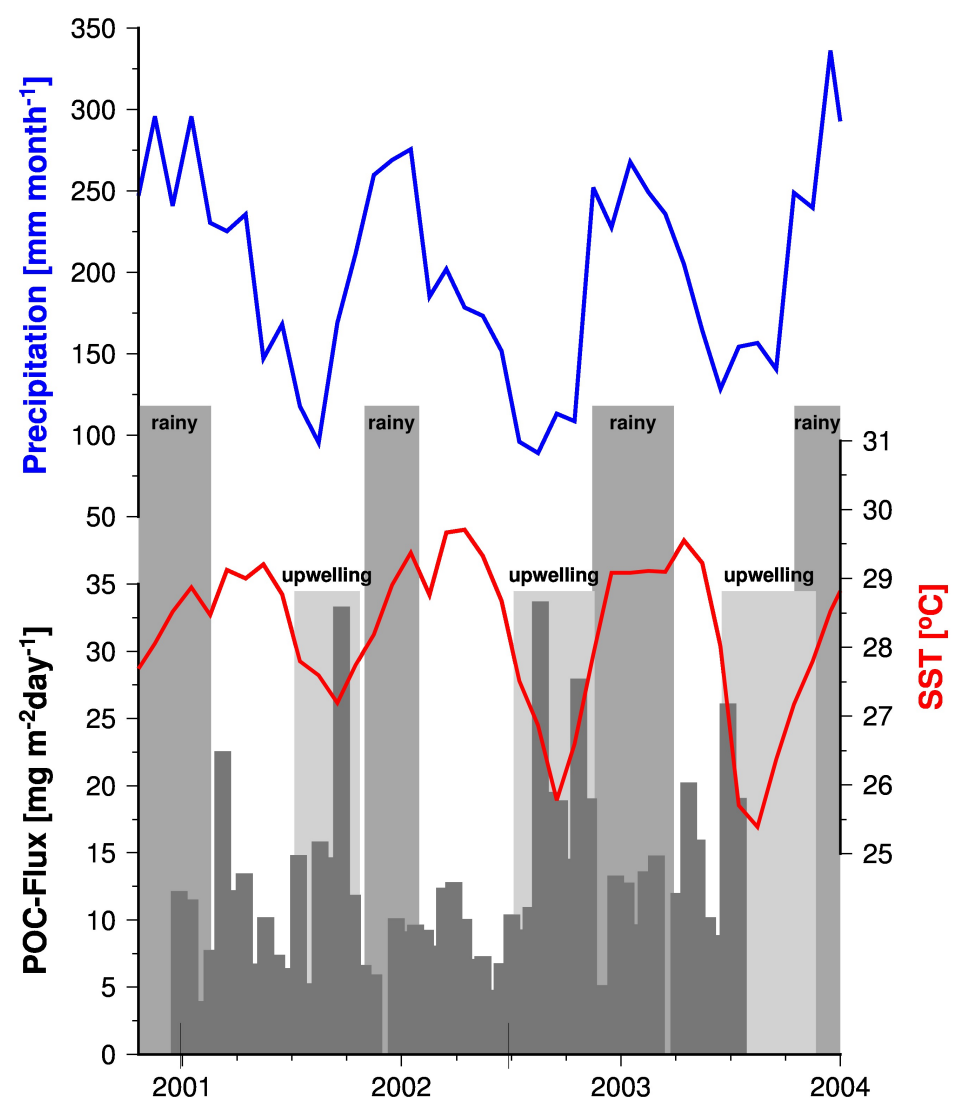


Biogeosciences Discuss., https://doi.org/10.5194/bg-2017-317

Manuscript under review for journal Biogeosciences

Discussion started: 25 August 2017

(c) Author(s) 2017. CC BY 4.0 License.

\section{(c) (i)}

Figure 7

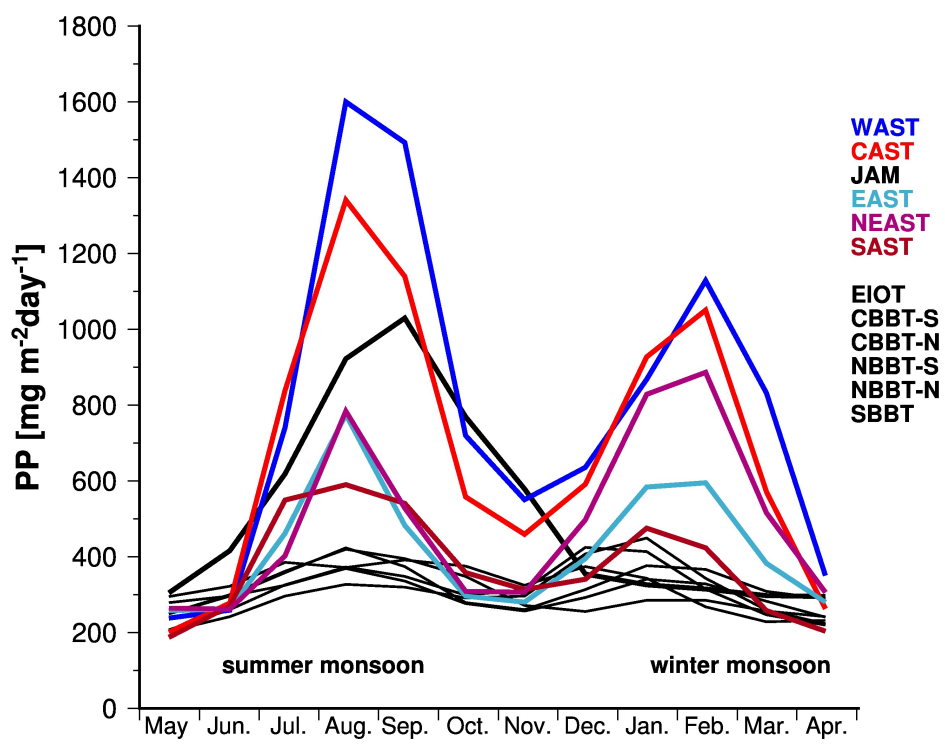


Biogeosciences Discuss., https://doi.org/10.5194/bg-2017-317

Manuscript under review for journal Biogeosciences

Discussion started: 25 August 2017

(c) Author(s) 2017. CC BY 4.0 License.

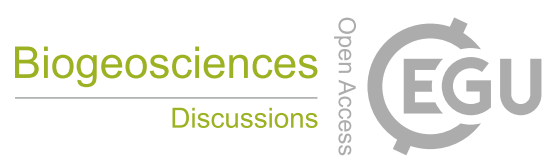

(c) (i)

Figure 8

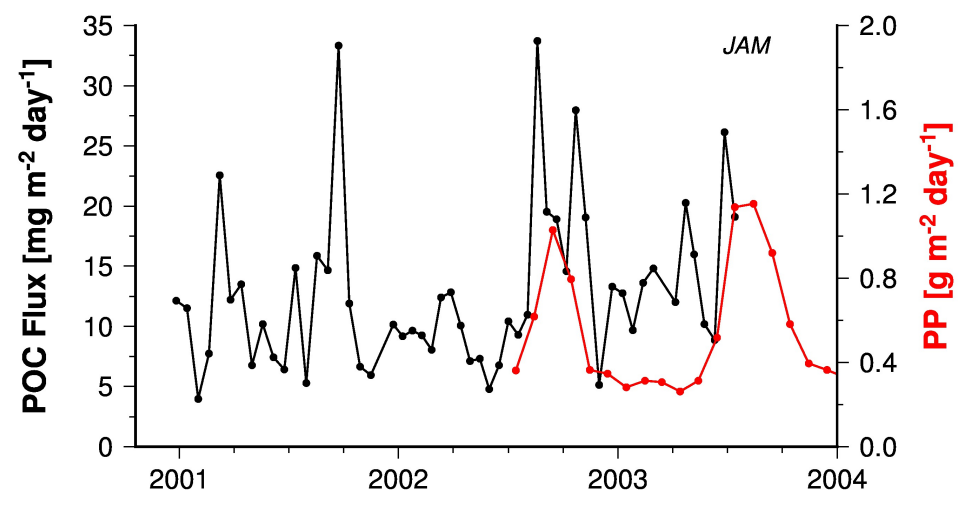


Biogeosciences Discuss., https://doi.org/10.5194/bg-2017-317

Manuscript under review for journal Biogeosciences

Discussion started: 25 August 2017

(c) Author(s) 2017. CC BY 4.0 License.

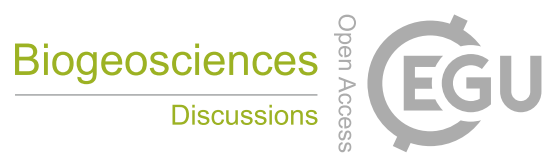
(c) (i)

Figure 9
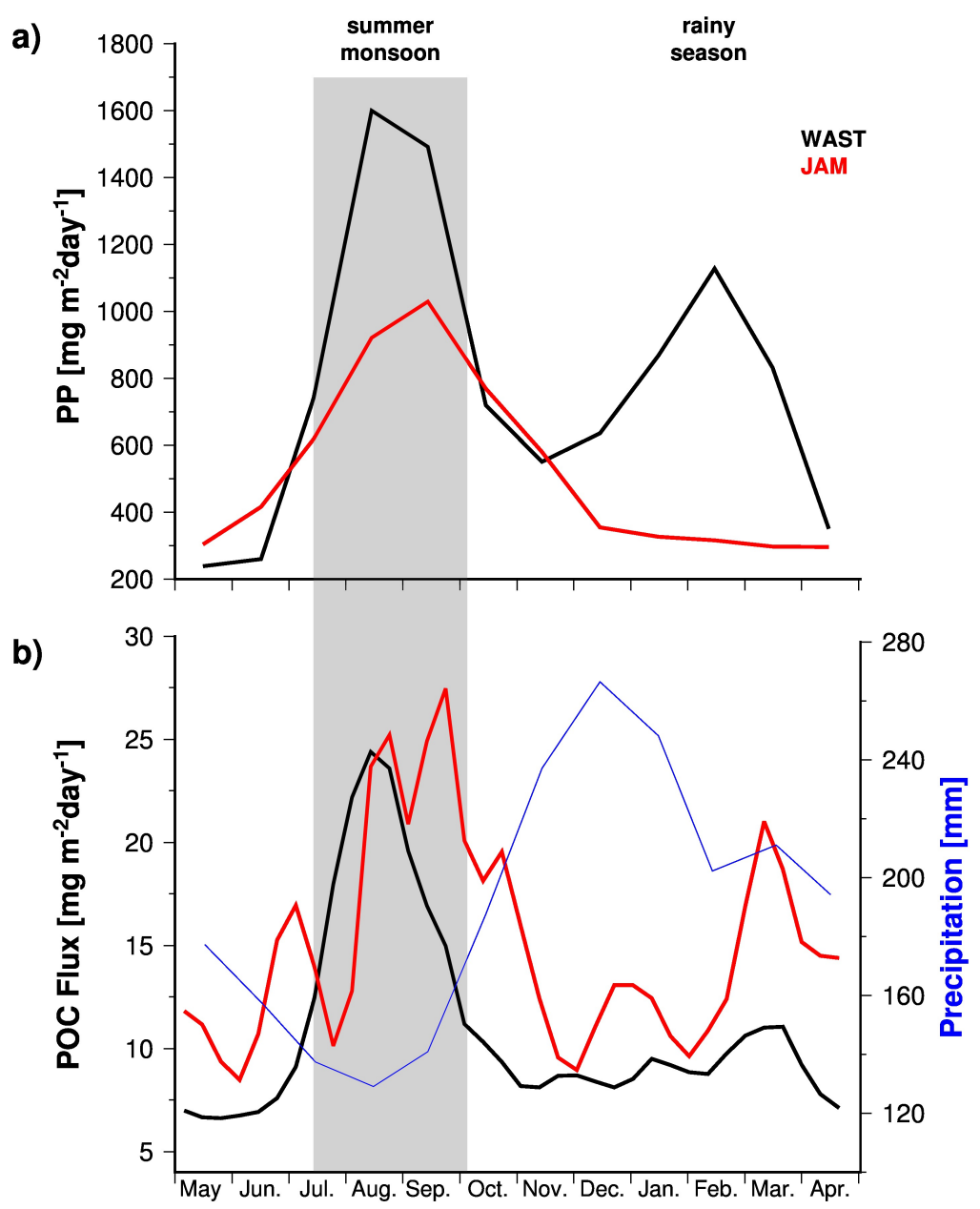
Biogeosciences Discuss., https://doi.org/10.5194/bg-2017-317

Manuscript under review for journal Biogeosciences

Discussion started: 25 August 2017

(c) Author(s) 2017. CC BY 4.0 License.

(a) (1)

Figure 10
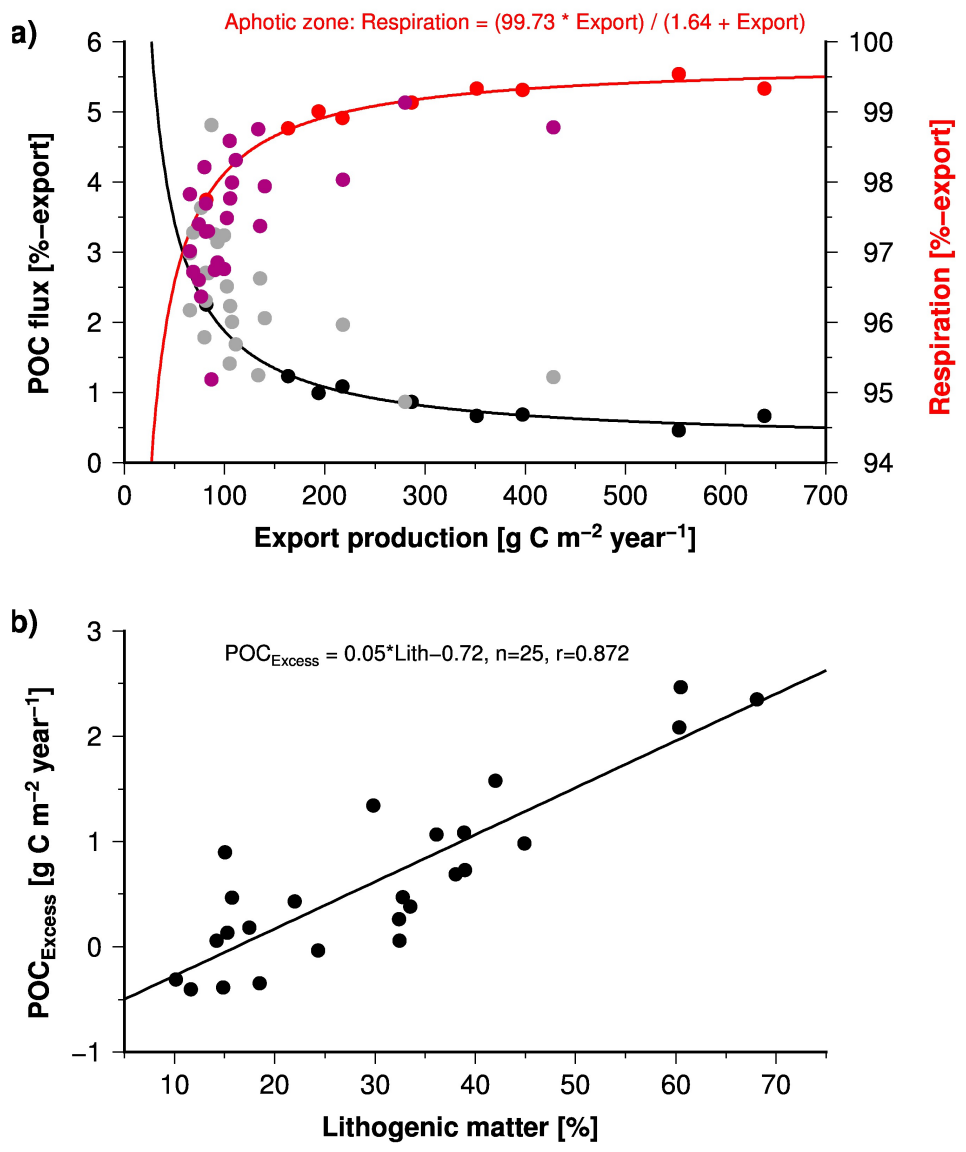
Biogeosciences Discuss., https://doi.org/10.5194/bg-2017-317

Manuscript under review for journal Biogeosciences

Discussion started: 25 August 2017

(c) Author(s) 2017. CC BY 4.0 License.

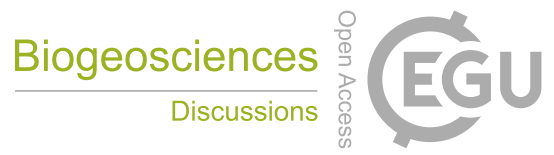

\section{(c) (i)}

Figure 11
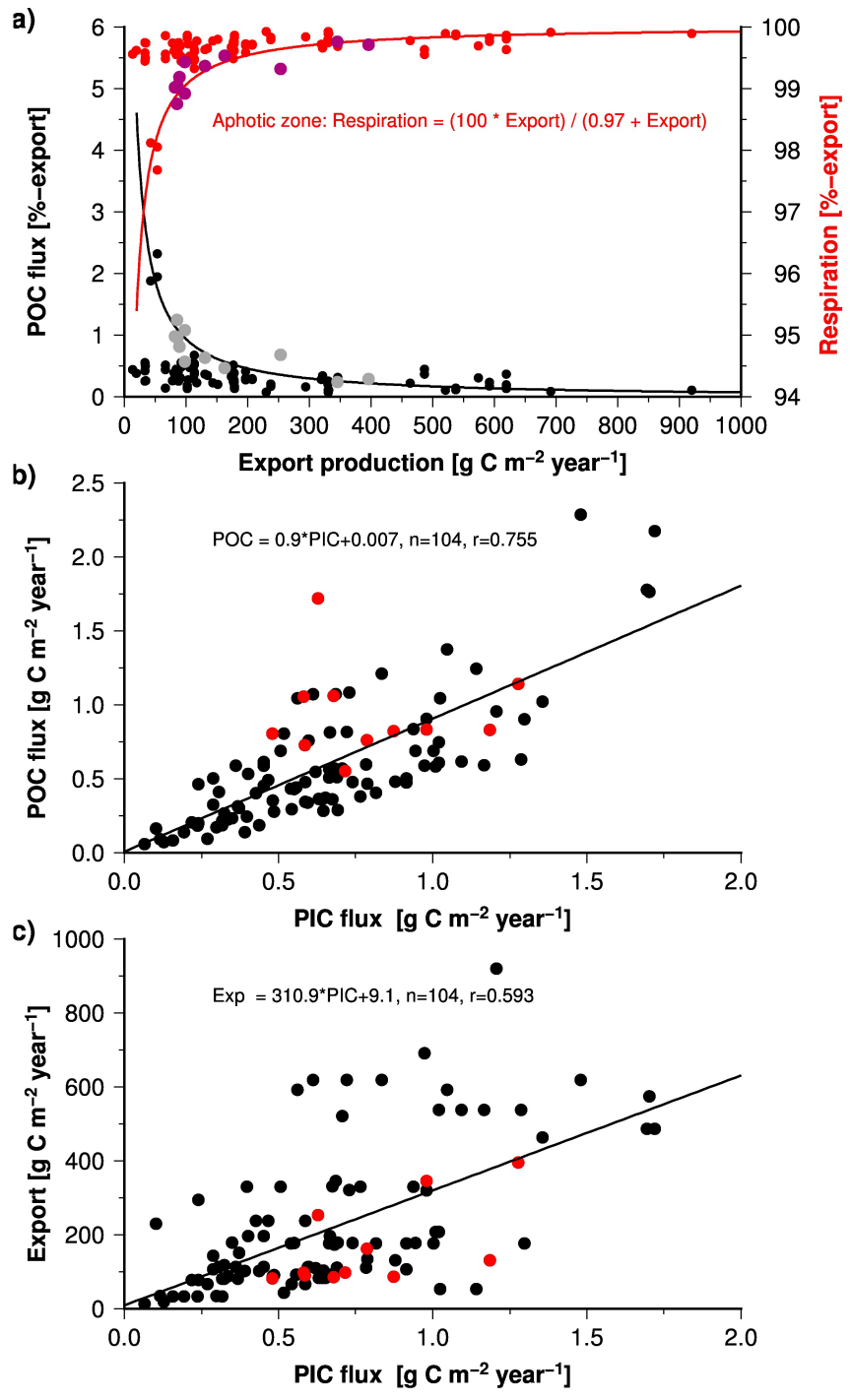
Biogeosciences Discuss., https://doi.org/10.5194/bg-2017-317

Manuscript under review for journal Biogeosciences

Discussion started: 25 August 2017

(C) Author(s) 2017. CC BY 4.0 License.

Figure 12

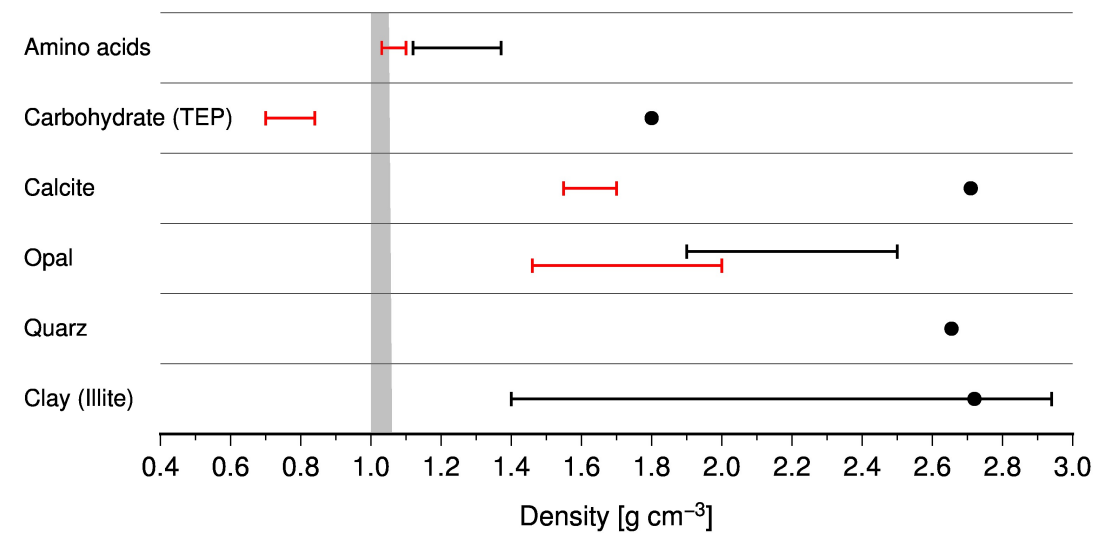


Biogeosciences Discuss., https://doi.org/10.5194/bg-2017-317

Manuscript under review for journal Biogeosciences

Discussion started: 25 August 2017

(c) Author(s) 2017. CC BY 4.0 License.

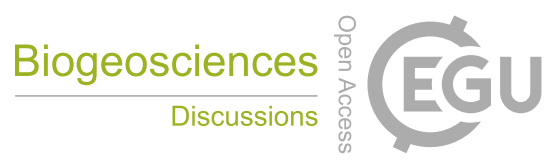

(c) $\underset{\mathrm{By}}{(i)}$

Figure 13
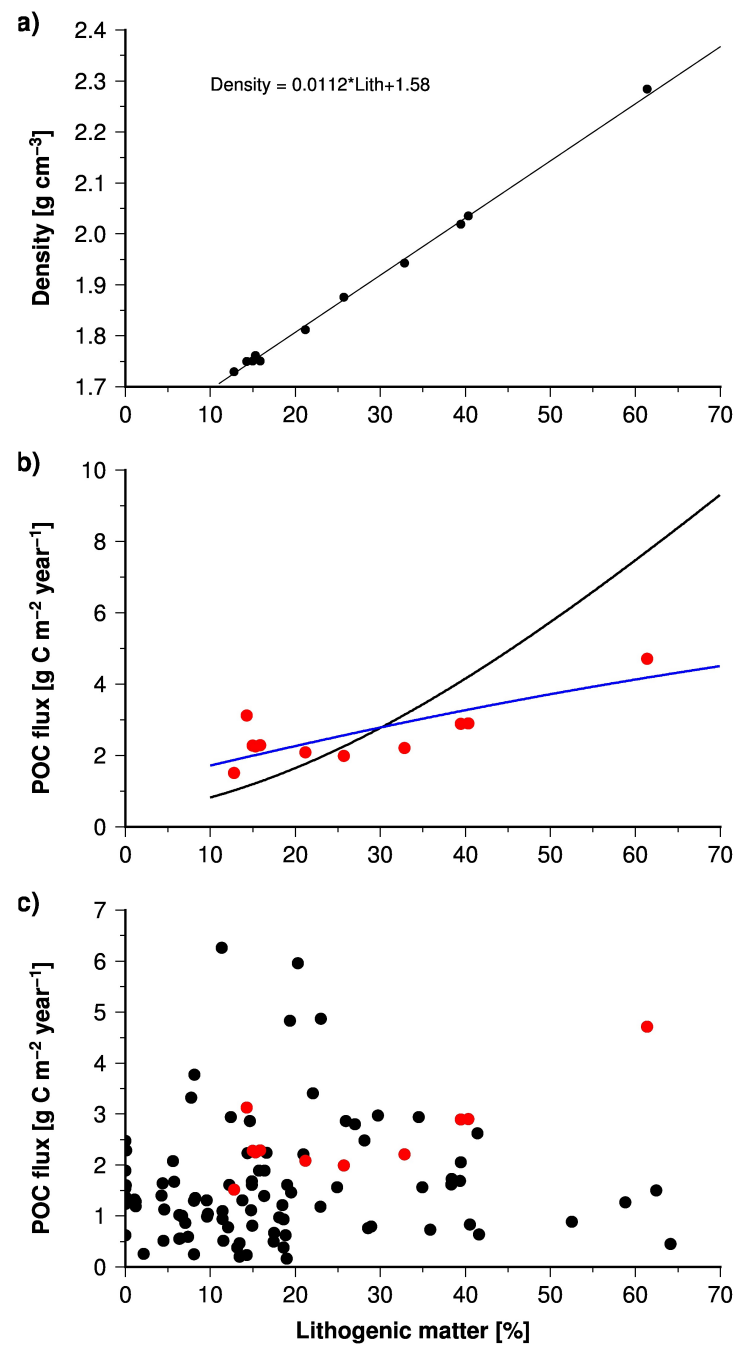

5 
Biogeosciences Discuss., https://doi.org/10.5194/bg-2017-317

Manuscript under review for journal Biogeosciences

Discussion started: 25 August 2017

(c) Author(s) 2017. CC BY 4.0 License.

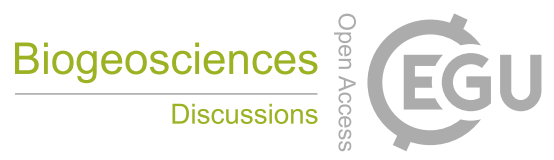

(c) (i)

Figure 14
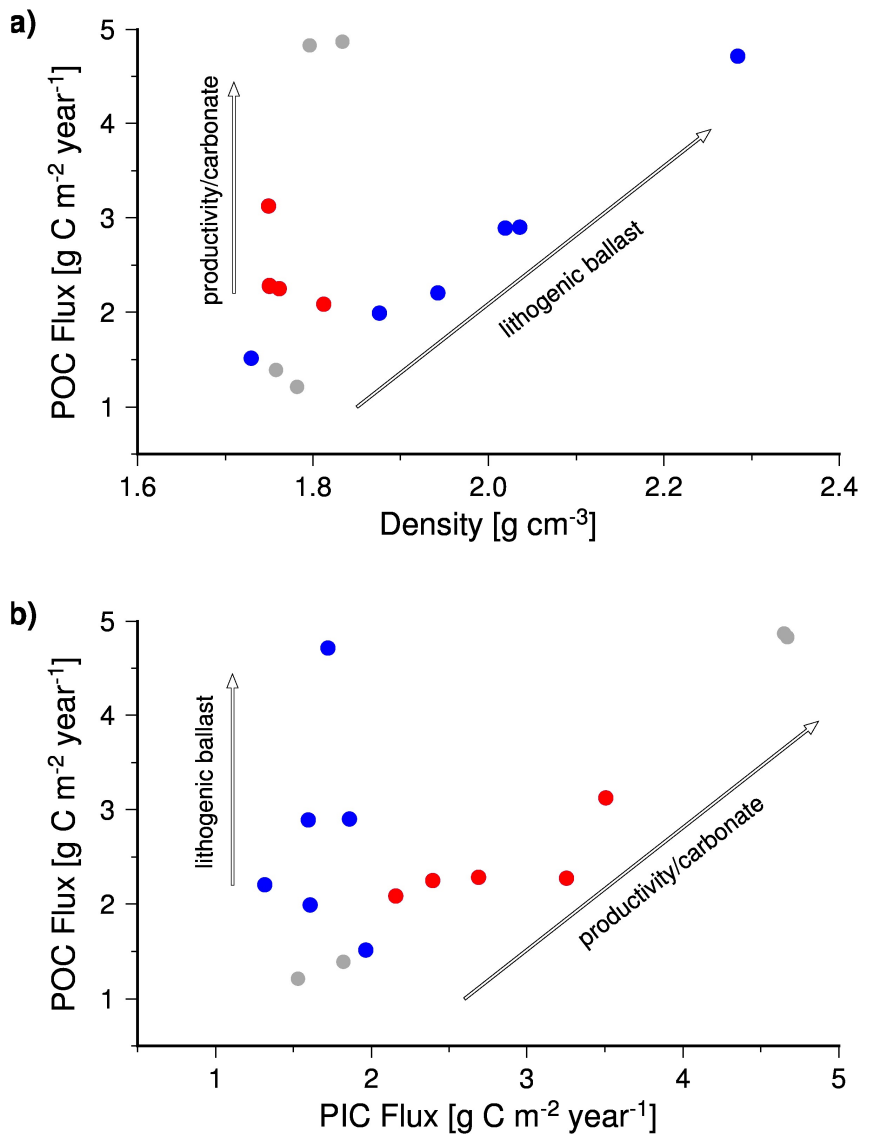
Biogeosciences Discuss., https://doi.org/10.5194/bg-2017-317

Manuscript under review for journal Biogeosciences

Discussion started: 25 August 2017

(c) Author(s) 2017. CC BY 4.0 License.

(c) (i)

Figure 15

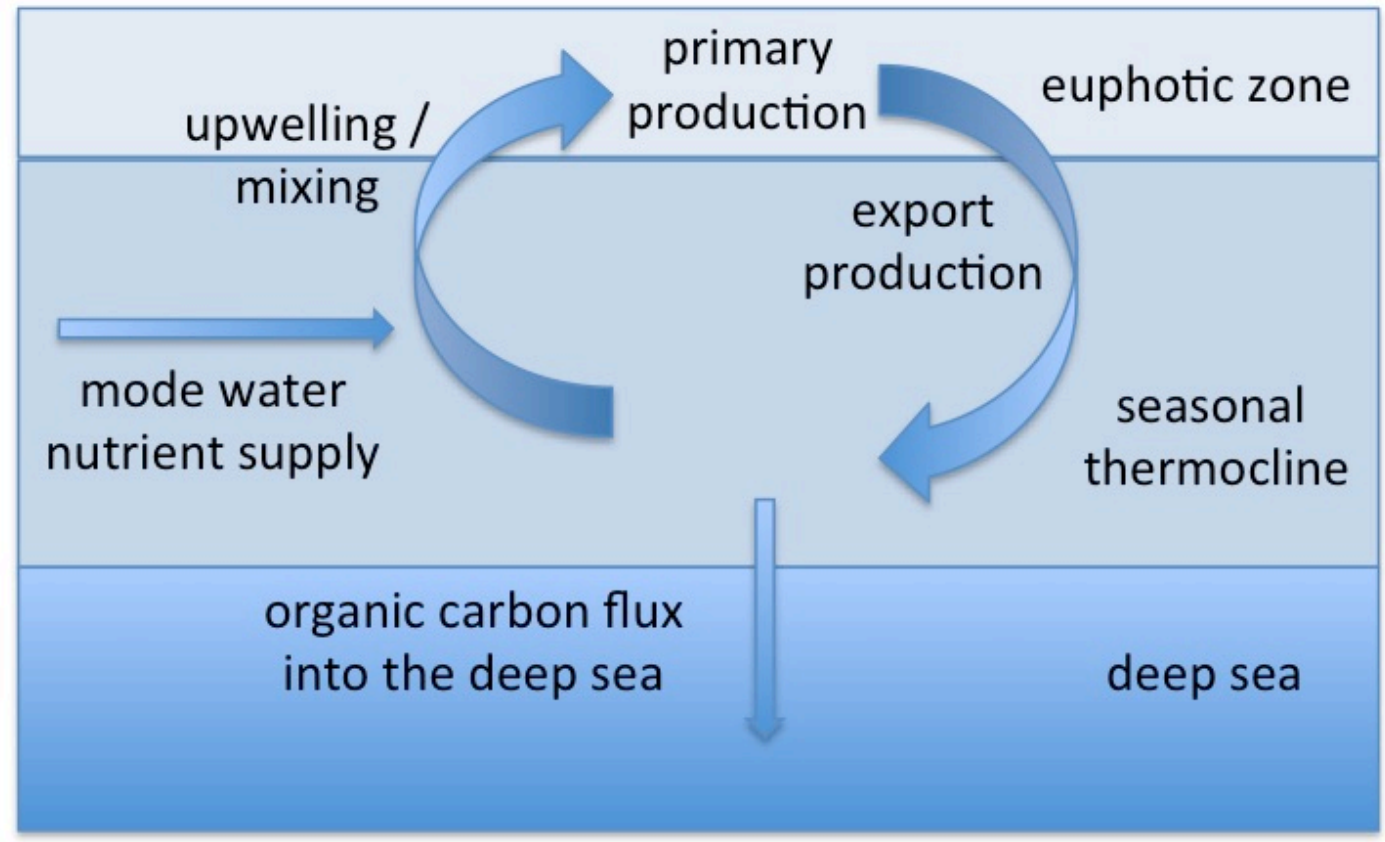


Biogeosciences Discuss., https://doi.org/10.5194/bg-2017-317

Manuscript under review for journal Biogeosciences

Discussion started: 25 August 2017

(c) Author(s) 2017. CC BY 4.0 License.

(c)

Figure 17

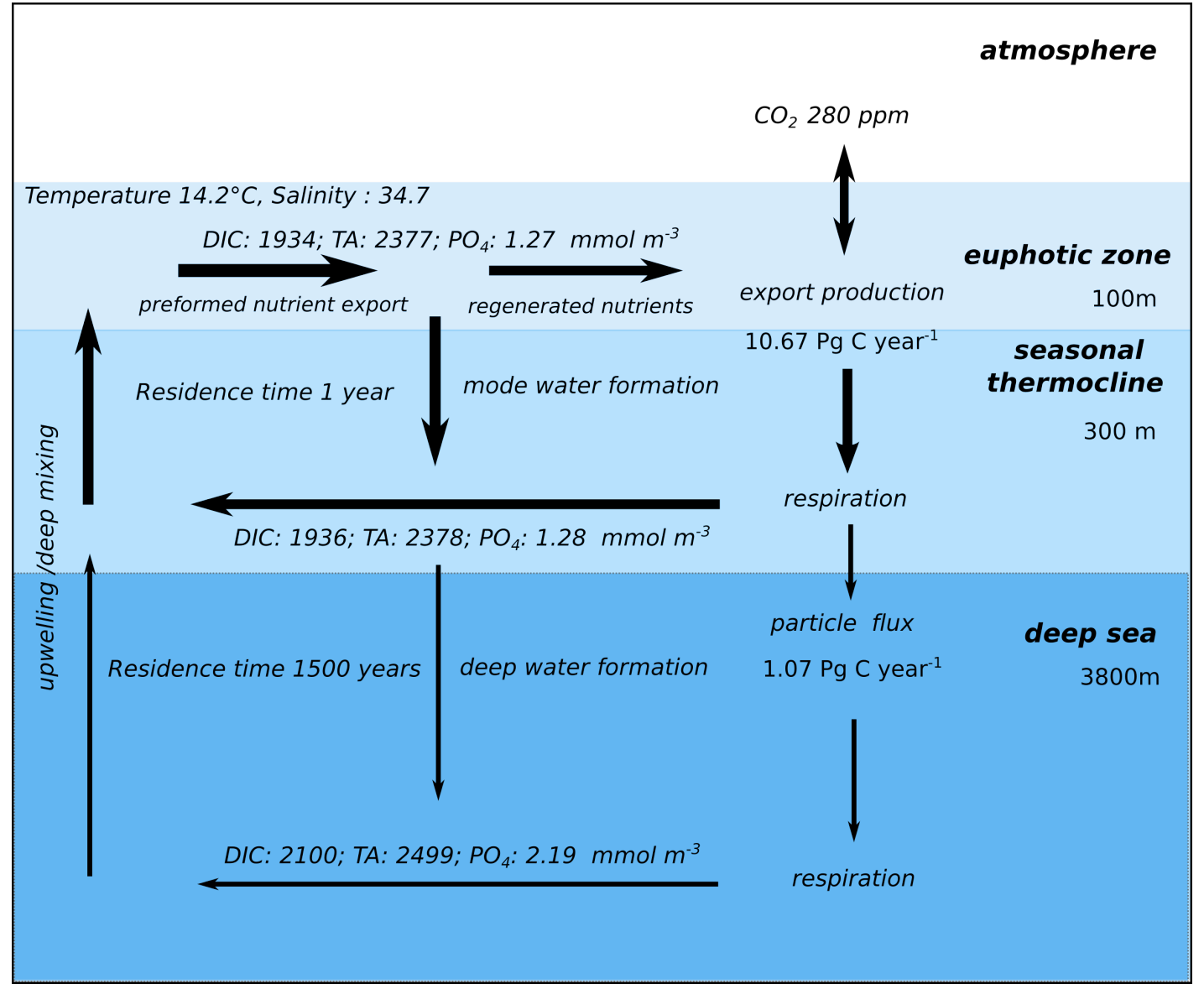

